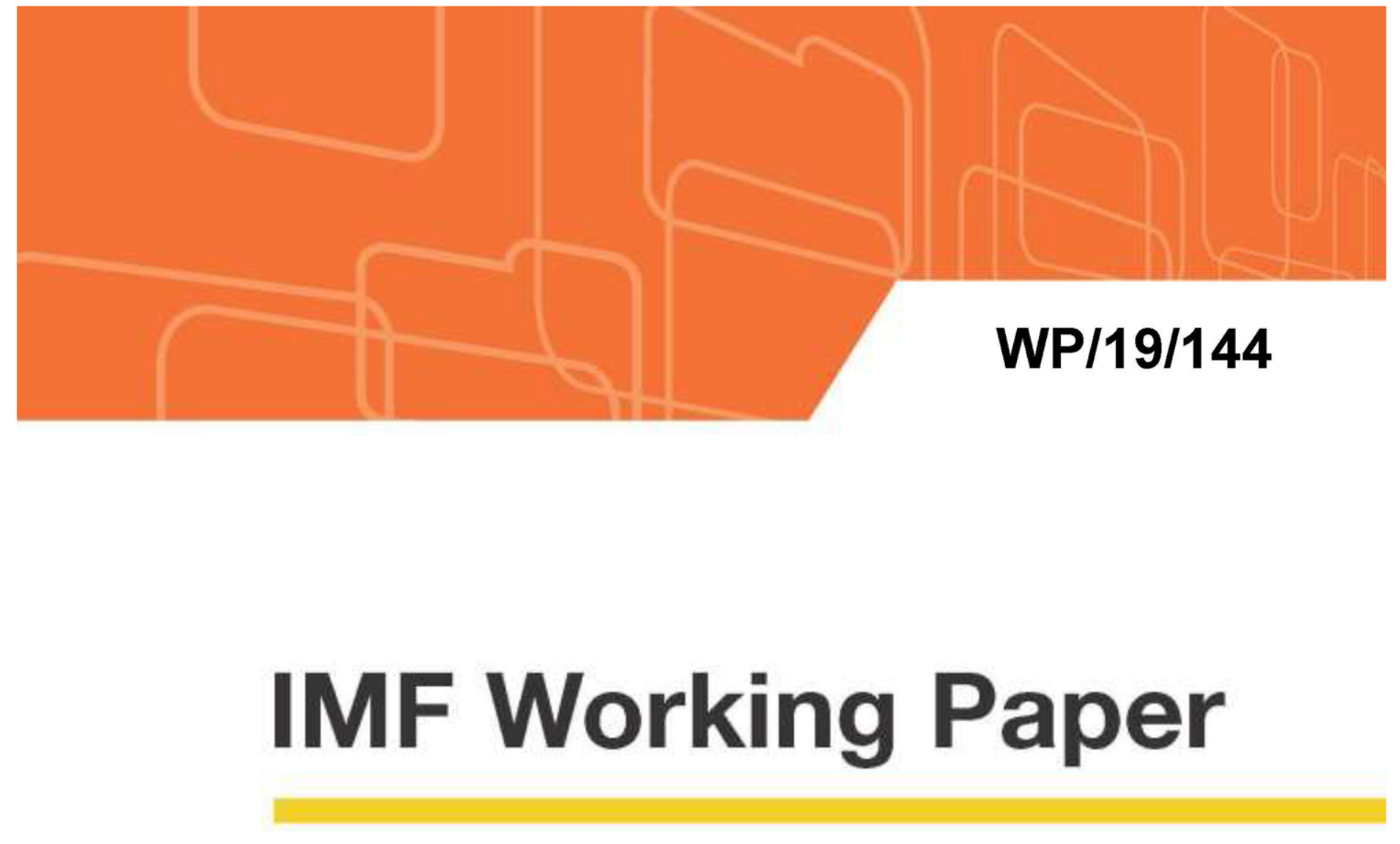

\title{
Explaining High Unemployment in ECCU Countries
}

by Ronald James, Jemma Lafeuillee, Mike Xin Li, Gonzalo Salinas, and Yevgeniya

Savchenko

IMF Working Papers describe research in progress by the author(s) and are published to elicit comments and to encourage debate. The views expressed in IMF Working Papers are those of the author(s) and do not necessarily represent the views of the IMF, its Executive Board, or IMF management. 


\section{WP/19/144}

\section{IMF Working Paper}

\section{Explaining High Unemployment in ECCU Countries}

by Ronald James, Jemma Lafeuillee, Mike Xin Li, Gonzalo Salinas, and Yevgeniya

Savchenko

IMF Working Papers describe research in progress by the author(s) and are published to elicit comments and to encourage debate.

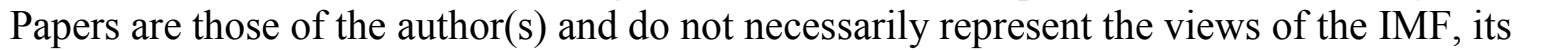

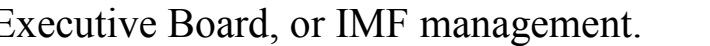

I NTER N ATION AL MONETARY FUND 


\title{
IMF Working Paper
}

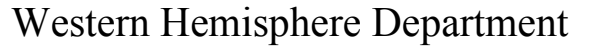

\section{Explaining High Unemployment in ECCU Countries \\ Prepared by Ronald James, Jemma Lafeuillee, Mike Xin Li, Gonzalo Salinas, and Yevgeniya Savchenko ${ }^{1}$}

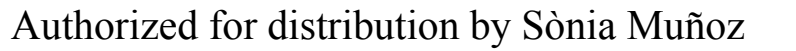

$\square \mathrm{l} \square \square \square$

IMF Working Papers describe research in progress by the author(s) and are published to

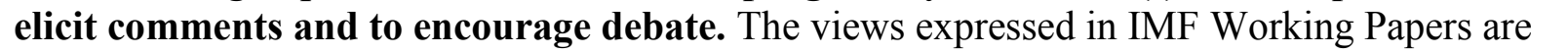
प

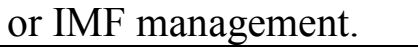

\begin{abstract}

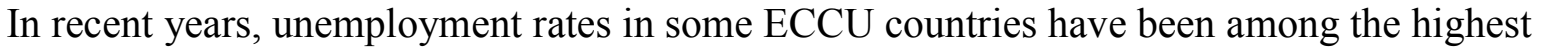

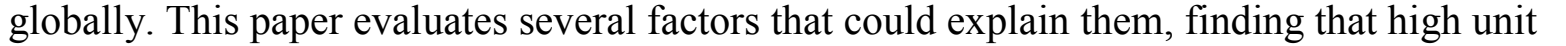

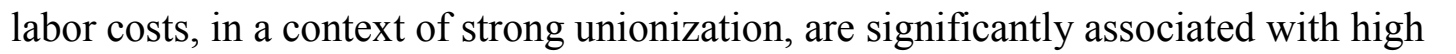

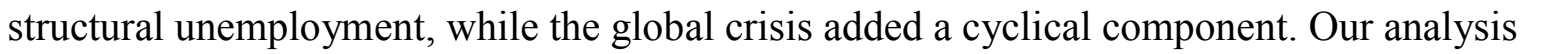

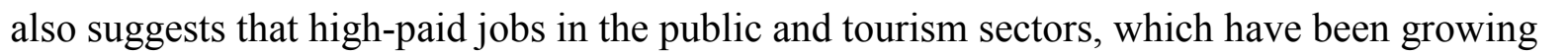

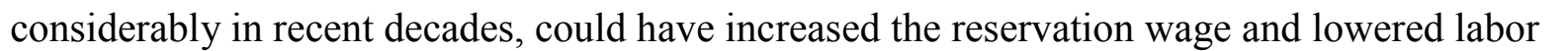

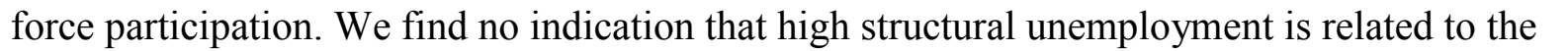

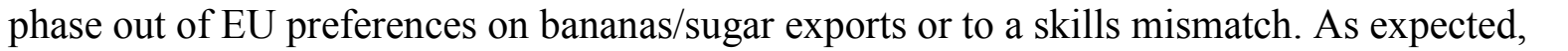

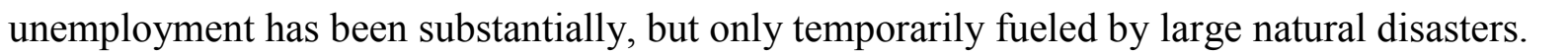

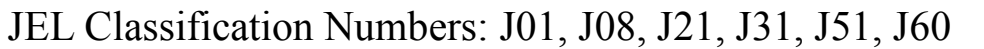

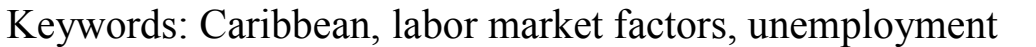

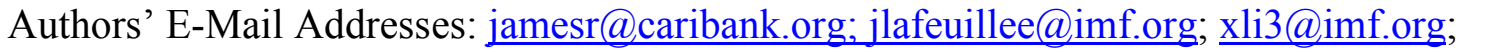

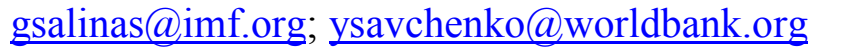

\footnotetext{
We thank Steve Brito for excellent research assistantship, as well as participants of our seminar at the IMF's
}

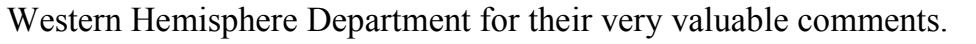




\section{Contents}

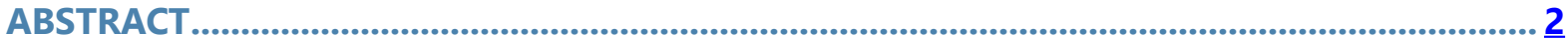

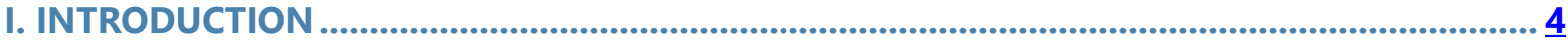

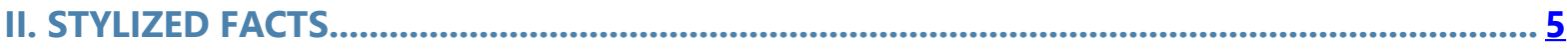

III. LABOR DEMAND: GLOBAL CYCLES, STRUCTURAL SHOCIKS, AND DISASTERS .................. 9

A. The global financial crisis and ECCU unemployment .................................................................... 9

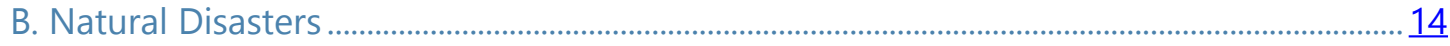

IV. LABOR SUPPLY: RESERVATION WAGES AND SKILLS MISMATCH .......................... 15

A. Do large remittances lower willingness to work? .......................................................................... 15

B. Does having a well-paid household member lower willingness to work? ............................. 17

C. Is there a skills mismatch structurally fueling unemployment? .......................................... 17

V. STRUCTURAL RIGIDITIES AND THE ROLE OF GOVERNMENT ................................. 18

A. High Unit Labor Costs and Unemployment ...............................................................................

B. Strong union activity in the wage setting process......................................................................... 22

C. Public sector wage demonstration effects.....................................................................................

VI. CONCLUSIONS AND POLICY RECOMMENDATIONS ............................................... 25 


\section{INTRODUCTION}

$\square$

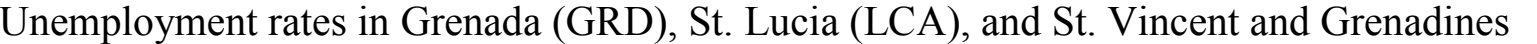

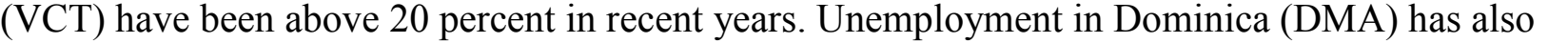

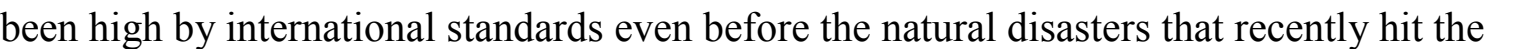

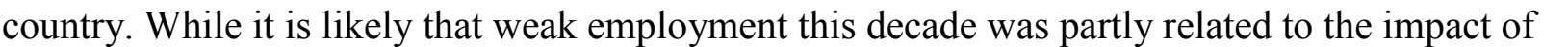

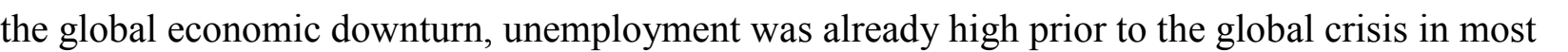

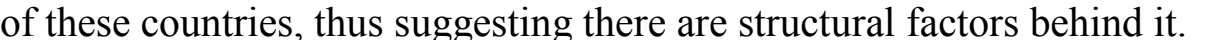
$\square$

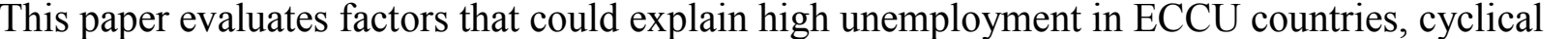

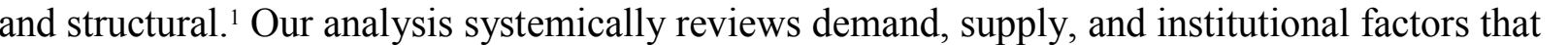

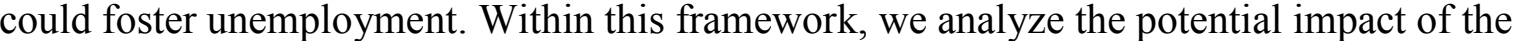

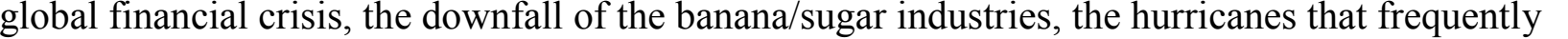

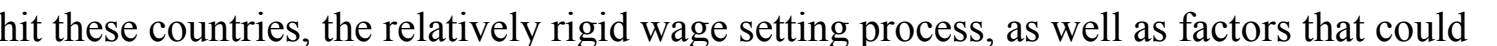
ए

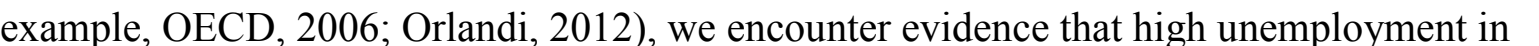

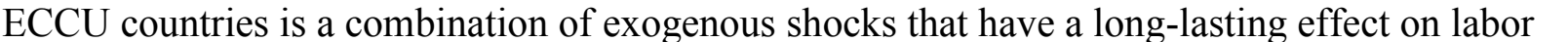

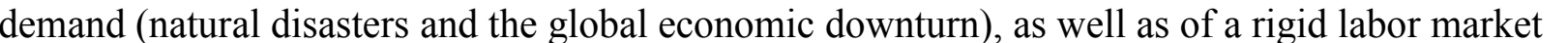

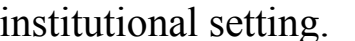

$\square$

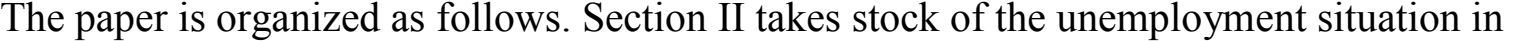

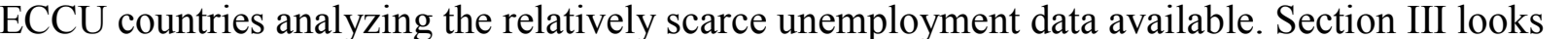

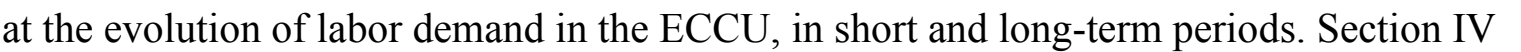

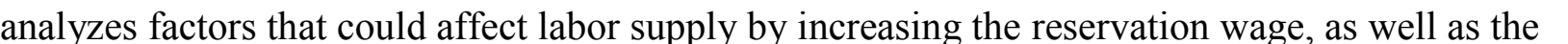

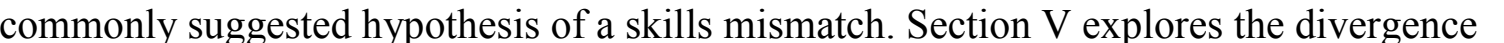

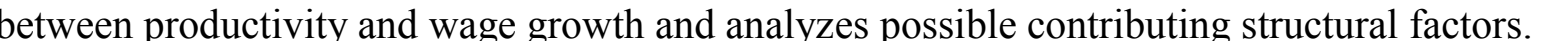

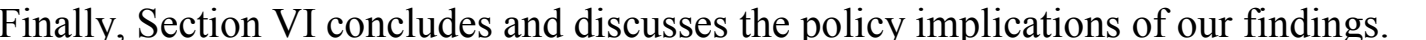
$\square$

世mmmmmmmmmmmmmmm

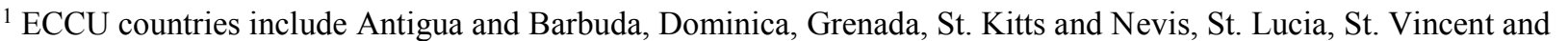

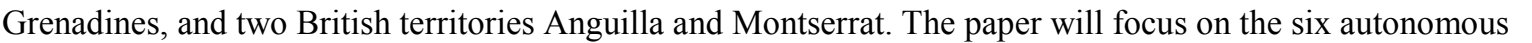

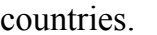

(continued...) $\square$ 


\section{STYLIZED FACTS}

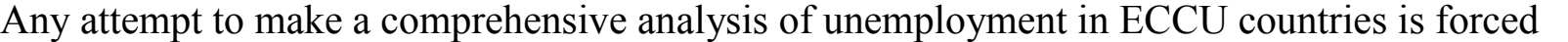

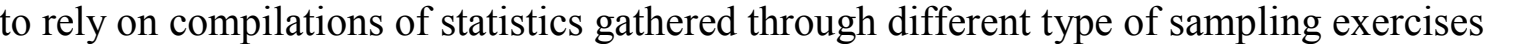

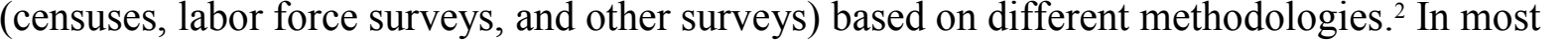

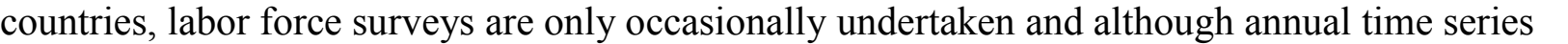

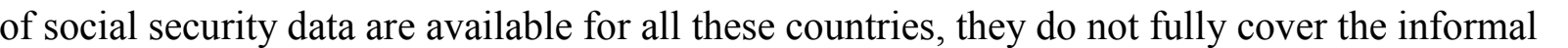

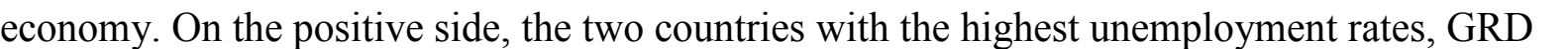

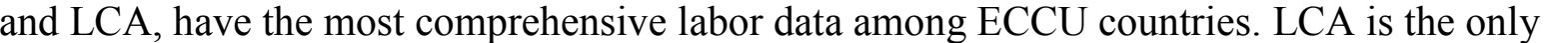

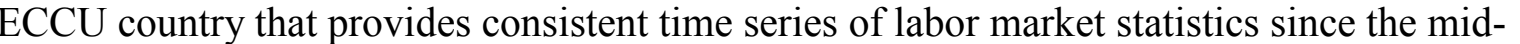

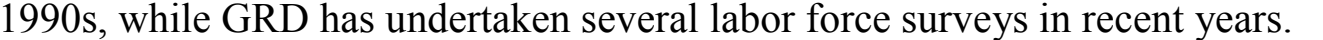

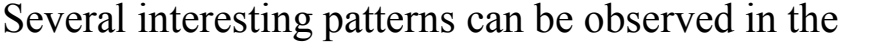

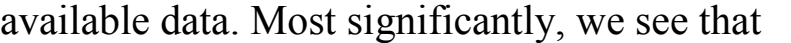

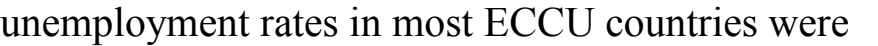

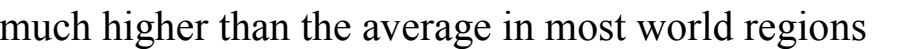

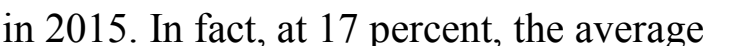

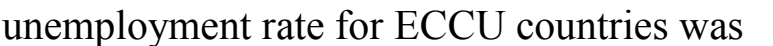

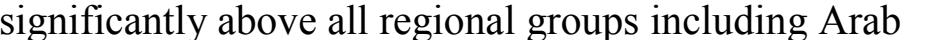

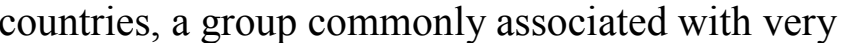

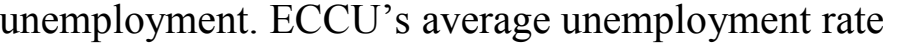

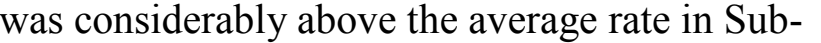

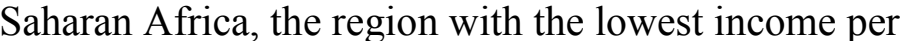

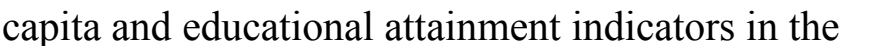
$\square \square \mathrm{DWH}$

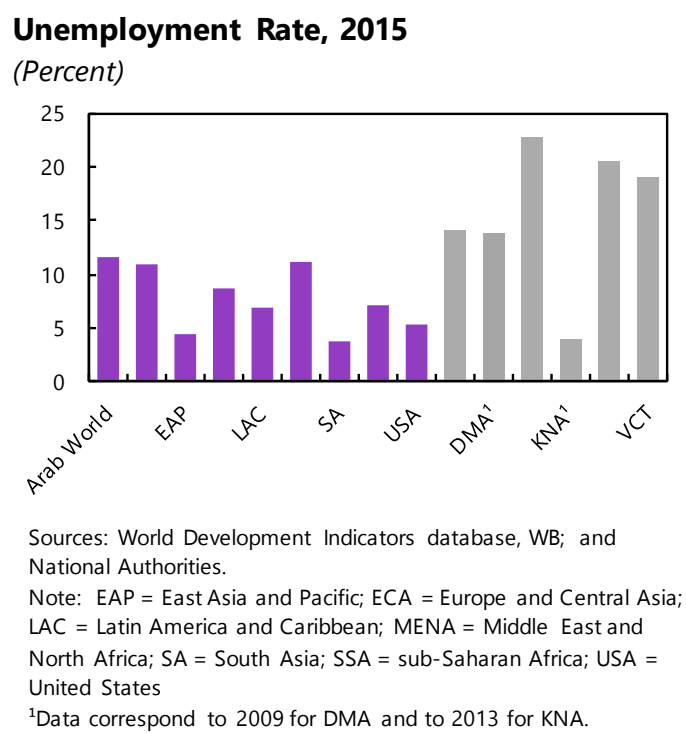

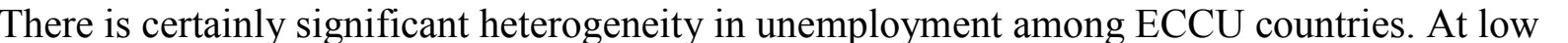

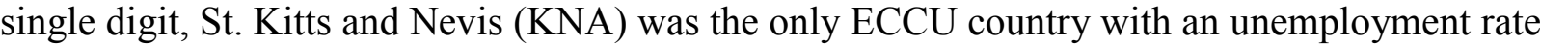

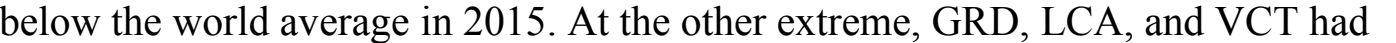

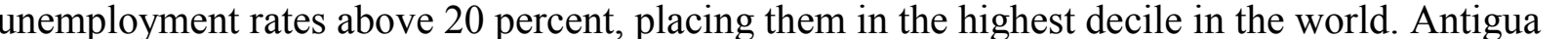

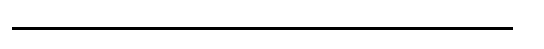

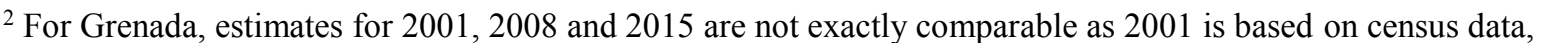

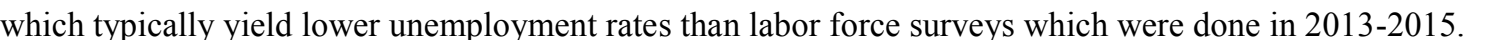

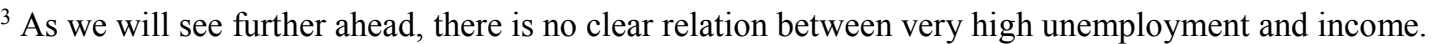




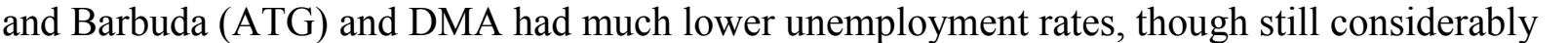

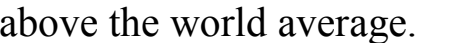

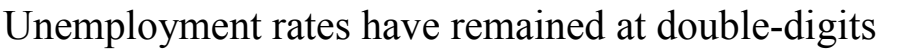

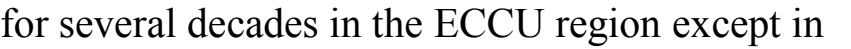

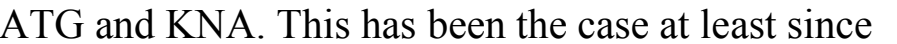

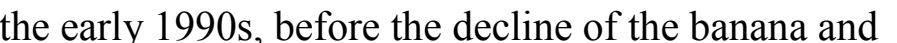

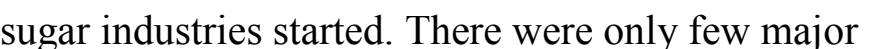

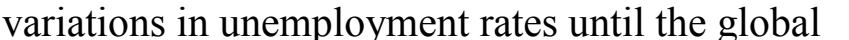

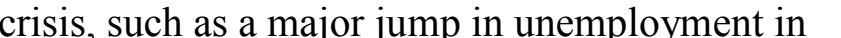

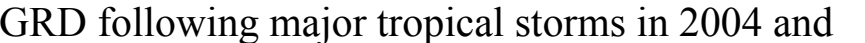

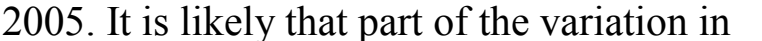

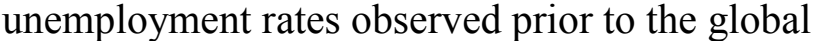

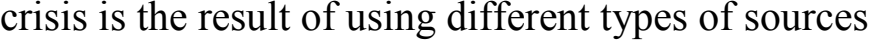
$\square\|1\|\|\| \square \square \square$
\end{abstract}

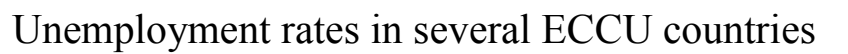

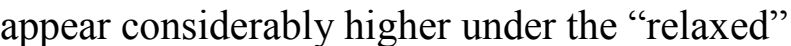

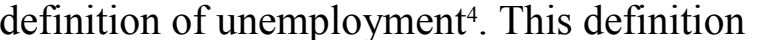

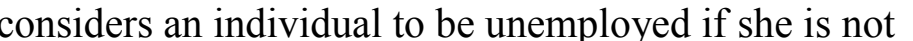

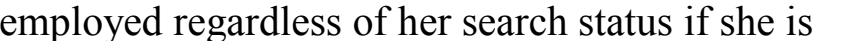

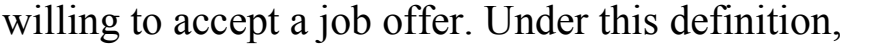

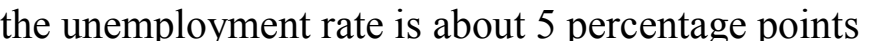
higher than under the "strict" definition in ATG,

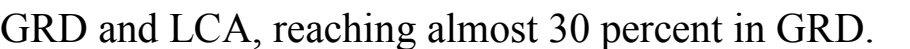

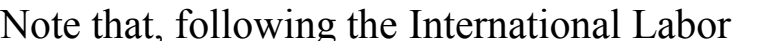

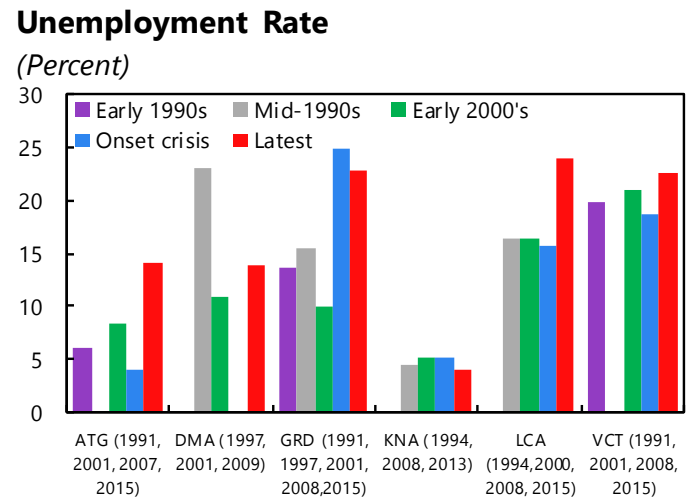

Sources: World Development Indicators database, WB; Youth Unemployment in the Caribbean (year); national authorities; and IMF staff calculations.

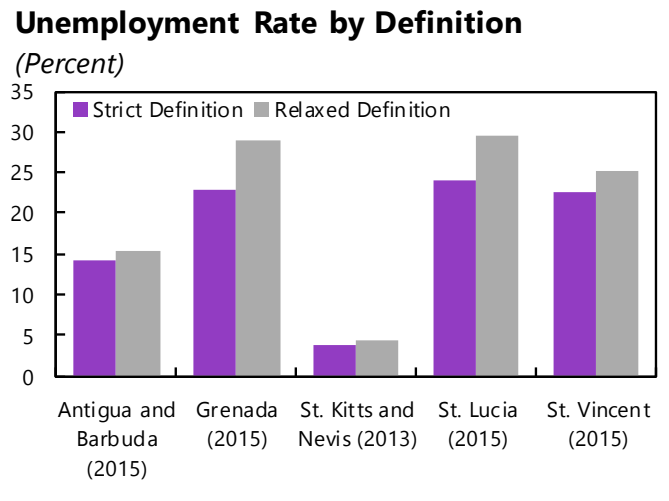

Sources: World Development Indicators database, WB; Youth Unemployment in the Caribbean (year); national authorities; and IMF staff calculations.

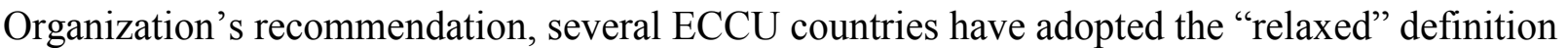

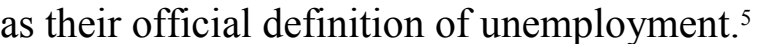

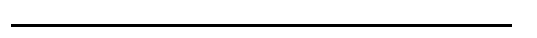

पThis definition stands in contrast to the more commonly used "strict" definition of unemployment, which

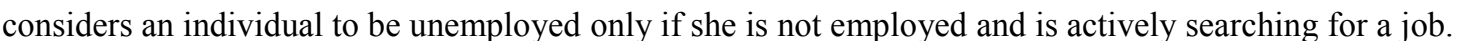

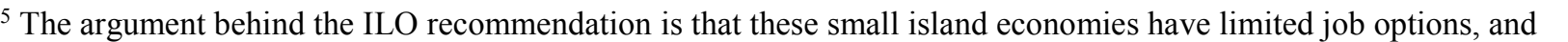
ए 


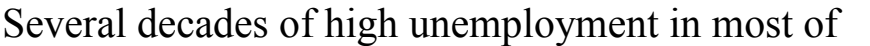

Structural Unemployment in St. Lucia ए।

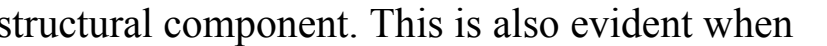

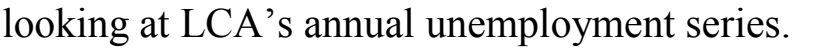

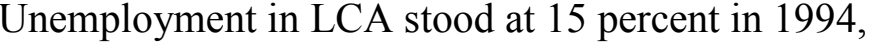

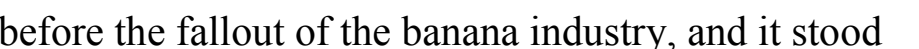

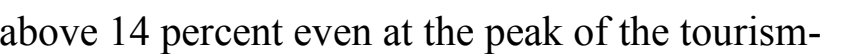

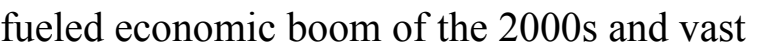

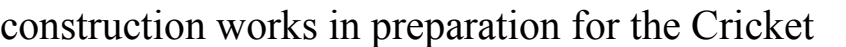
(Percent)

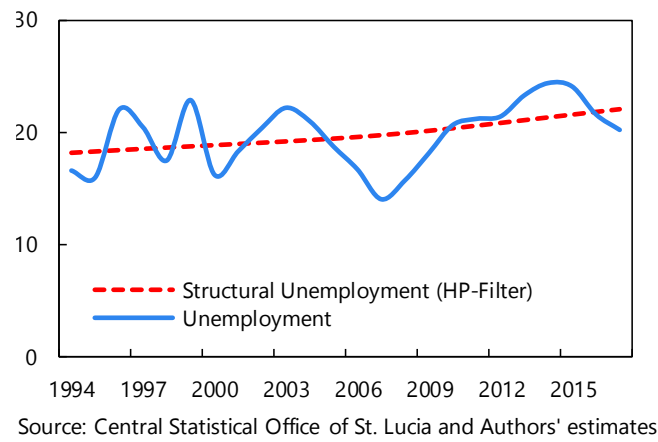

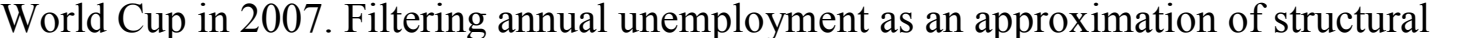

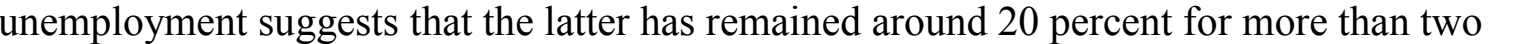

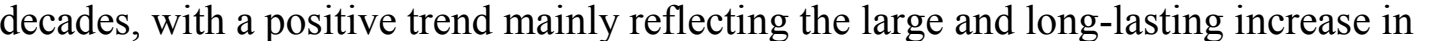

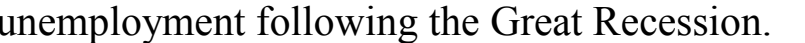

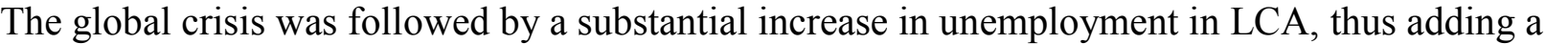

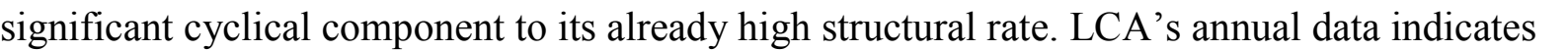
ए

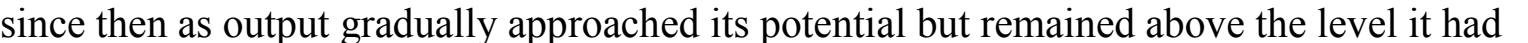

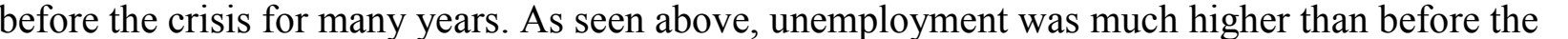

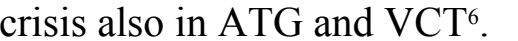

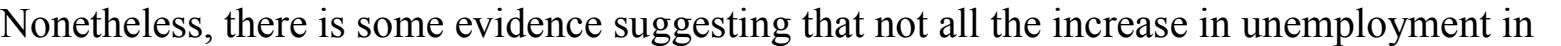

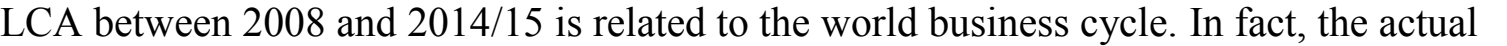
पा econometric estimates of the elasticity of unemployment to the output gap (Okun's Law) in

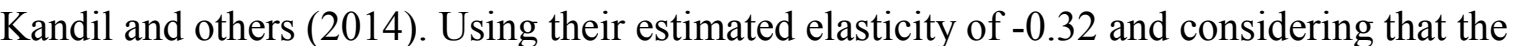

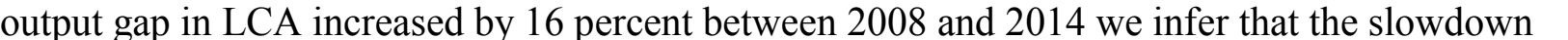

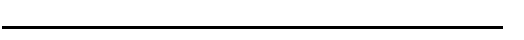

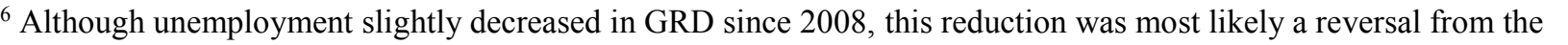

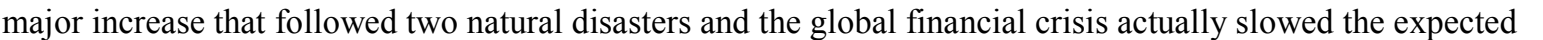

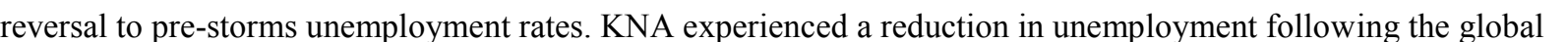

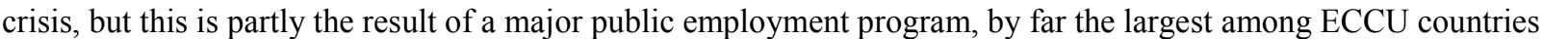

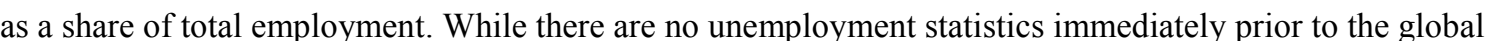

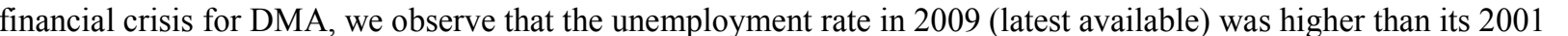
एामाणा 


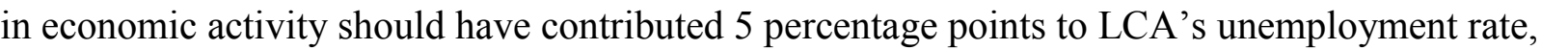

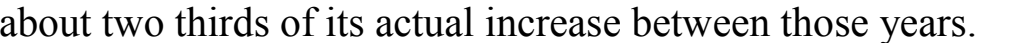

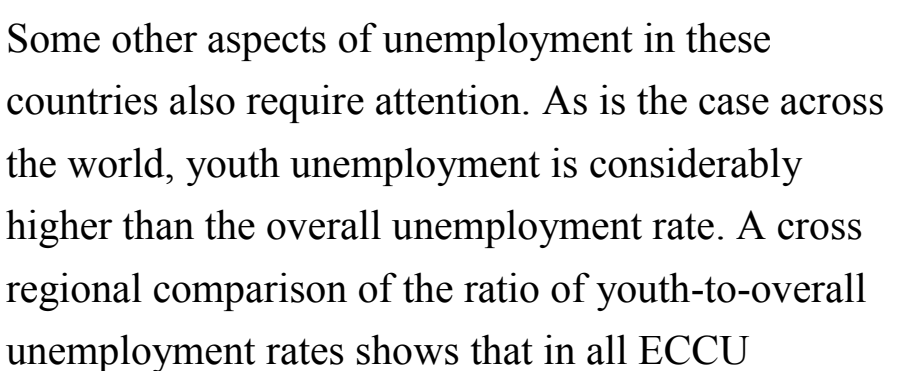

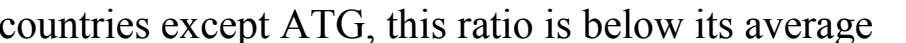

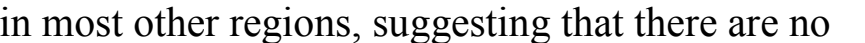

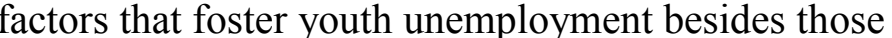

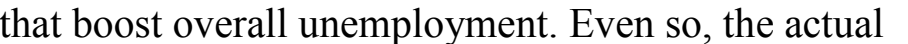

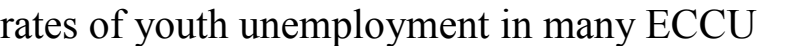

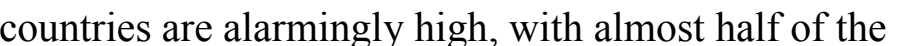

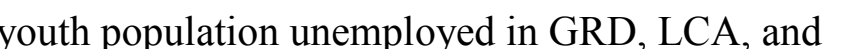

Youth to Overall Unemployment, 2014

(Ratio)

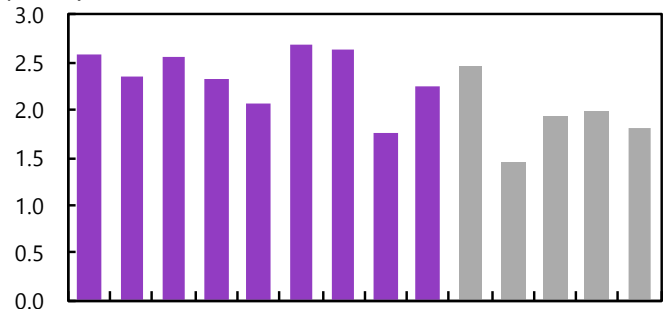

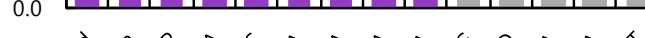

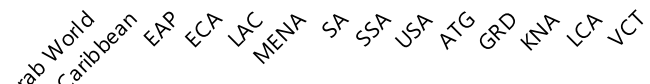

Sources: World Development Indicators database, WB; and national authorities.

Note: Percent of total labor force ages 15-24. EAP = East Asia and Pacific; $E C A=$ Europe and Central Asia; $L A C=$ Latin America and

Caribbean; MENA = Middle East and North Africa; SA = South Asia; SSA = sub-Saharan Africa; USA = United States; ATG = Antigua and Barbuda; GRD = Grenada; KNA = St Kitts and Nevis; LCA = St Lucia; and $\mathrm{VCT}=\mathrm{St}$ Vincent and the Grenadines.

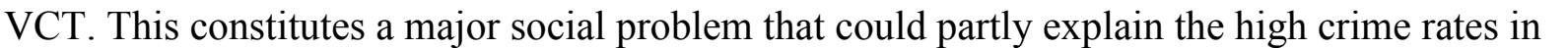

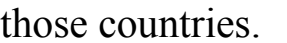

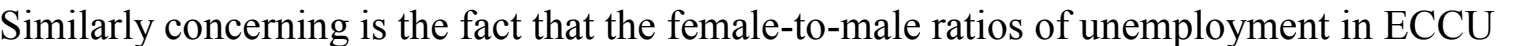

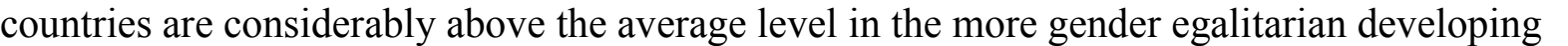
ए

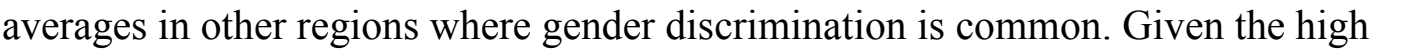

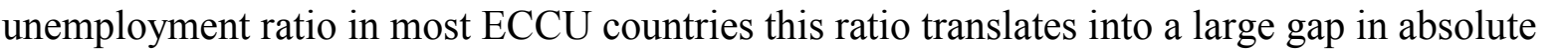

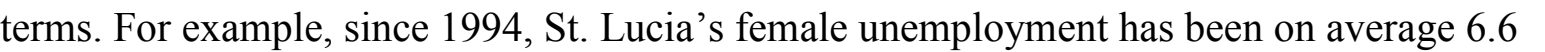

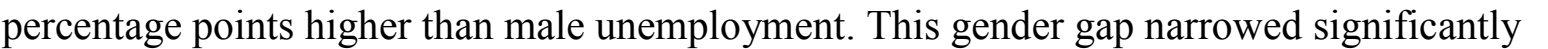
ए

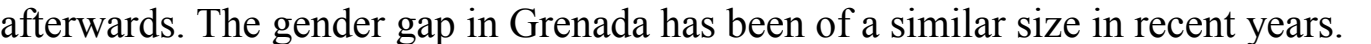


Female to Male Unemployment, 2014

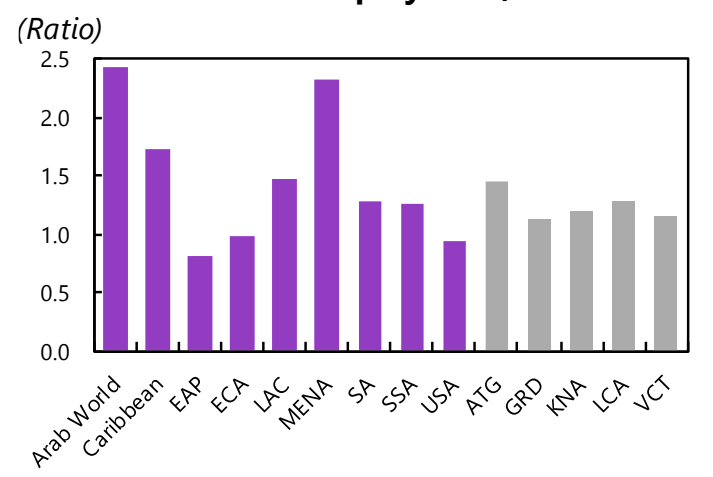

Sources: World Development Indicators database, WB; and national authorities.

Note: / Female divided by Male Unemployment Rate. EAP = East Asia and Pacific; ECA = Europe and Central Asia; LAC = Latin America and Caribbean; MENA = Middle East and North Africa; SA

= South Asia; SSA = sub-Saharan Africa; USA = United States; ATG = Antigua and Barbuda; GRD = Grenada; KNA = St Kitts and Nevis; $\mathrm{LCA}=$ St Lucia; and VCT = St Vincent and the Grenadines.
Unemployment by Gender in St. Lucia

(Percent)

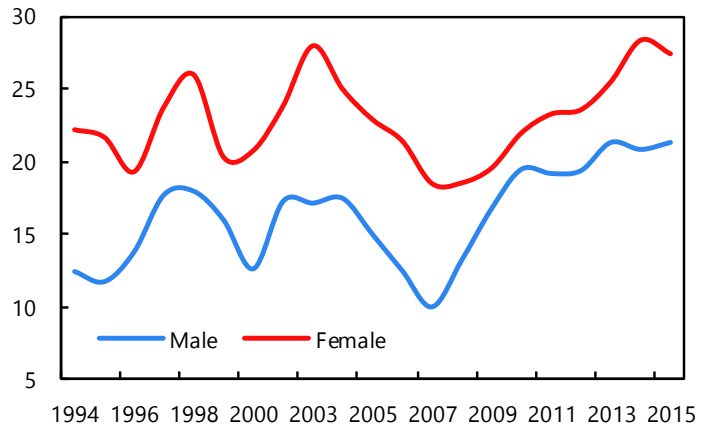

Sources: National authorities and IMF staff calculations.

\title{
III. LABOR DEMAND: GLOBAL CYCLES, STRUCTURAL SHOCKS, AND DISASTERS
}

\section{A. The global financial crisis and ECCU unemployment}

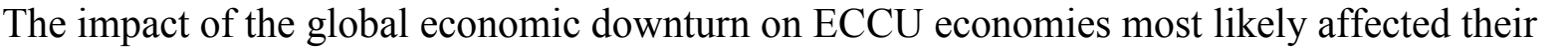

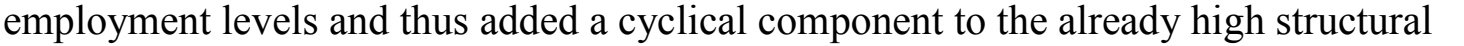

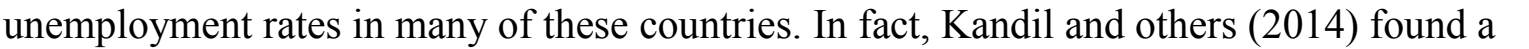

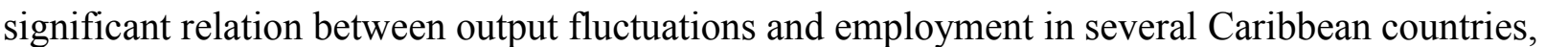

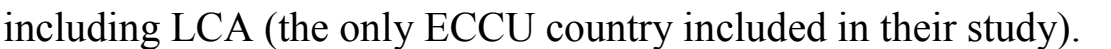

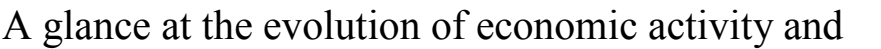

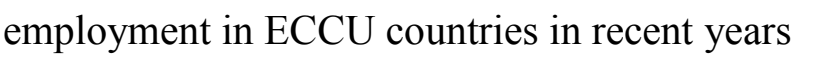

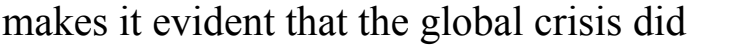

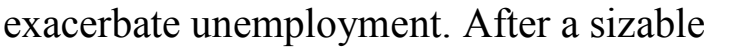

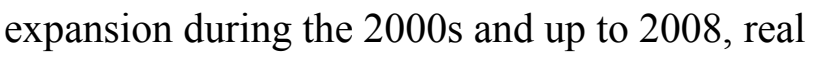

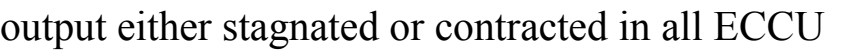

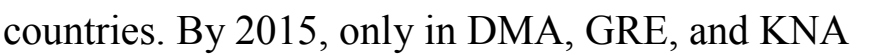

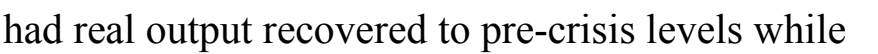

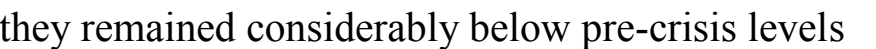

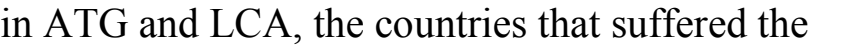

GDP Growth and Unemployment

(Percentage change in the corresponding years)

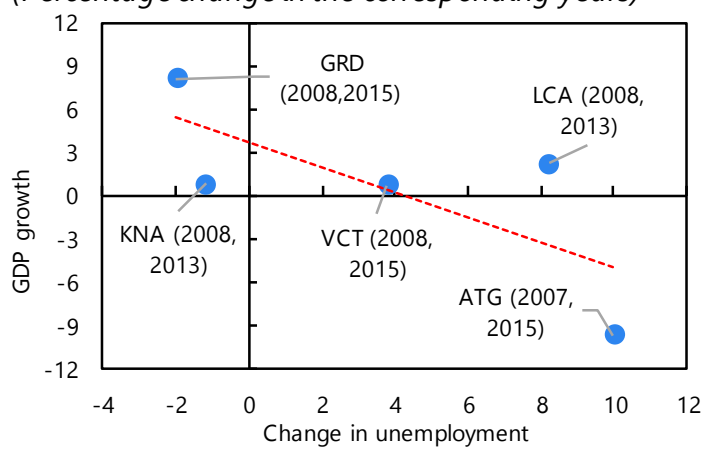

Source: World Economic Outlook database, IMF; national authorities; and IMF staff calculations. 


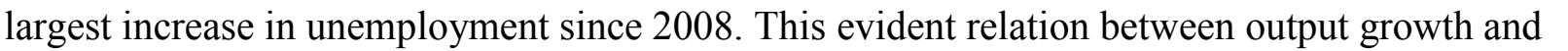

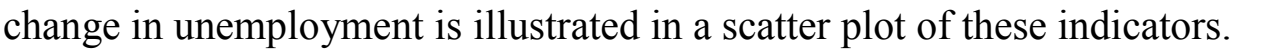

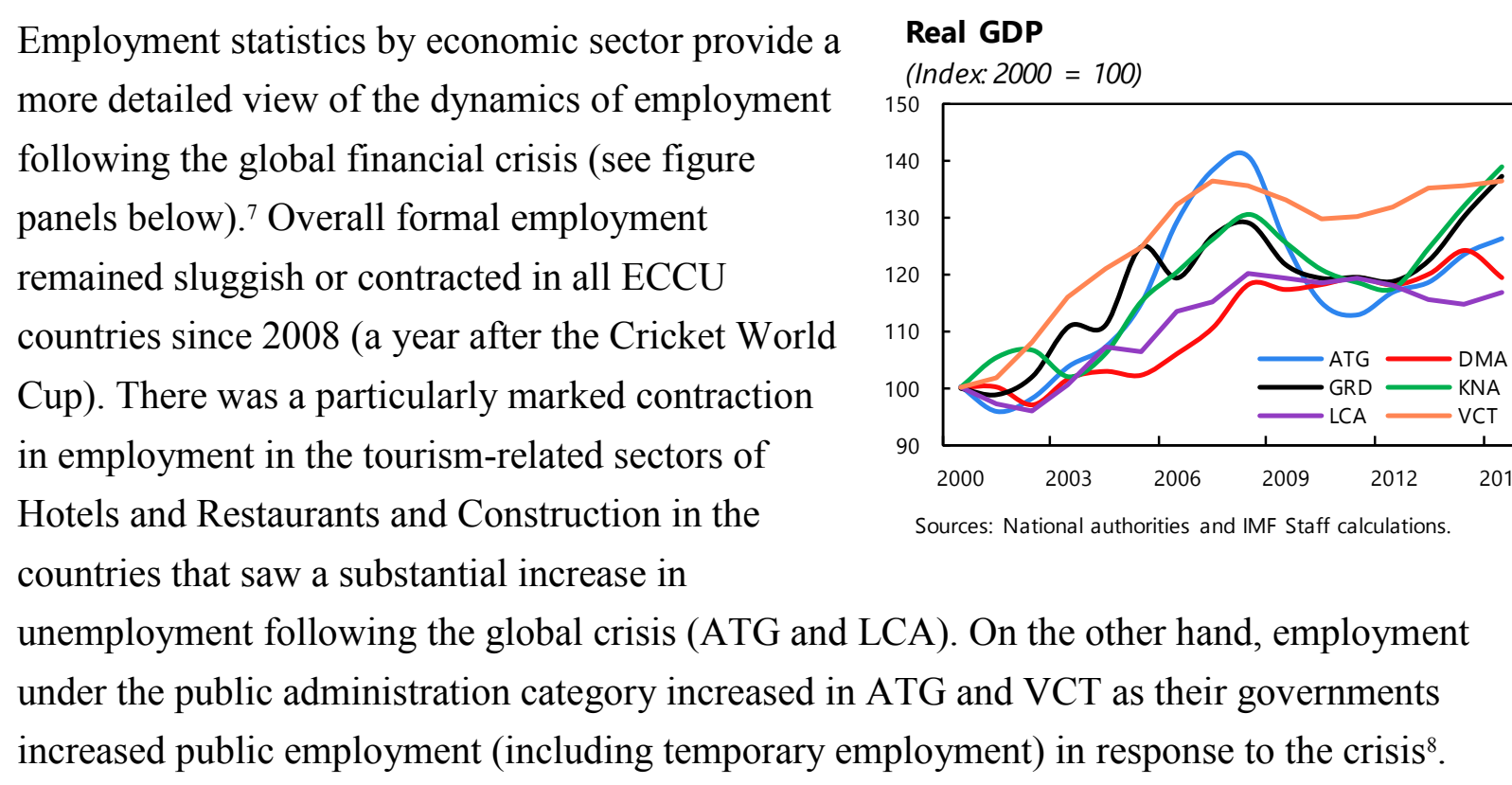

$\square$

$\square$

$\square$

$\square$

$\square$

$\square$

$\square$

$\square$

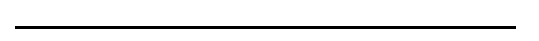

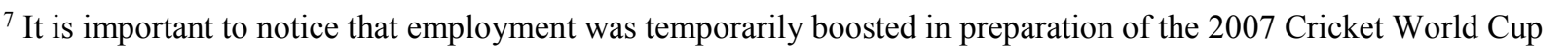

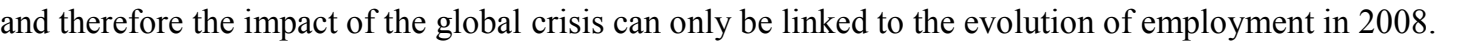

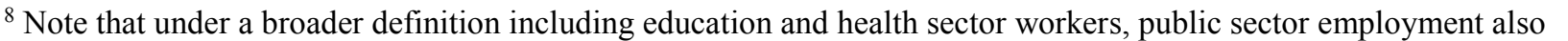

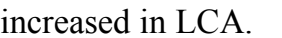

(CInternational Monetary Fund. Not for Redistribution 


\section{Formal Employment by Sector in ECCU Countries}

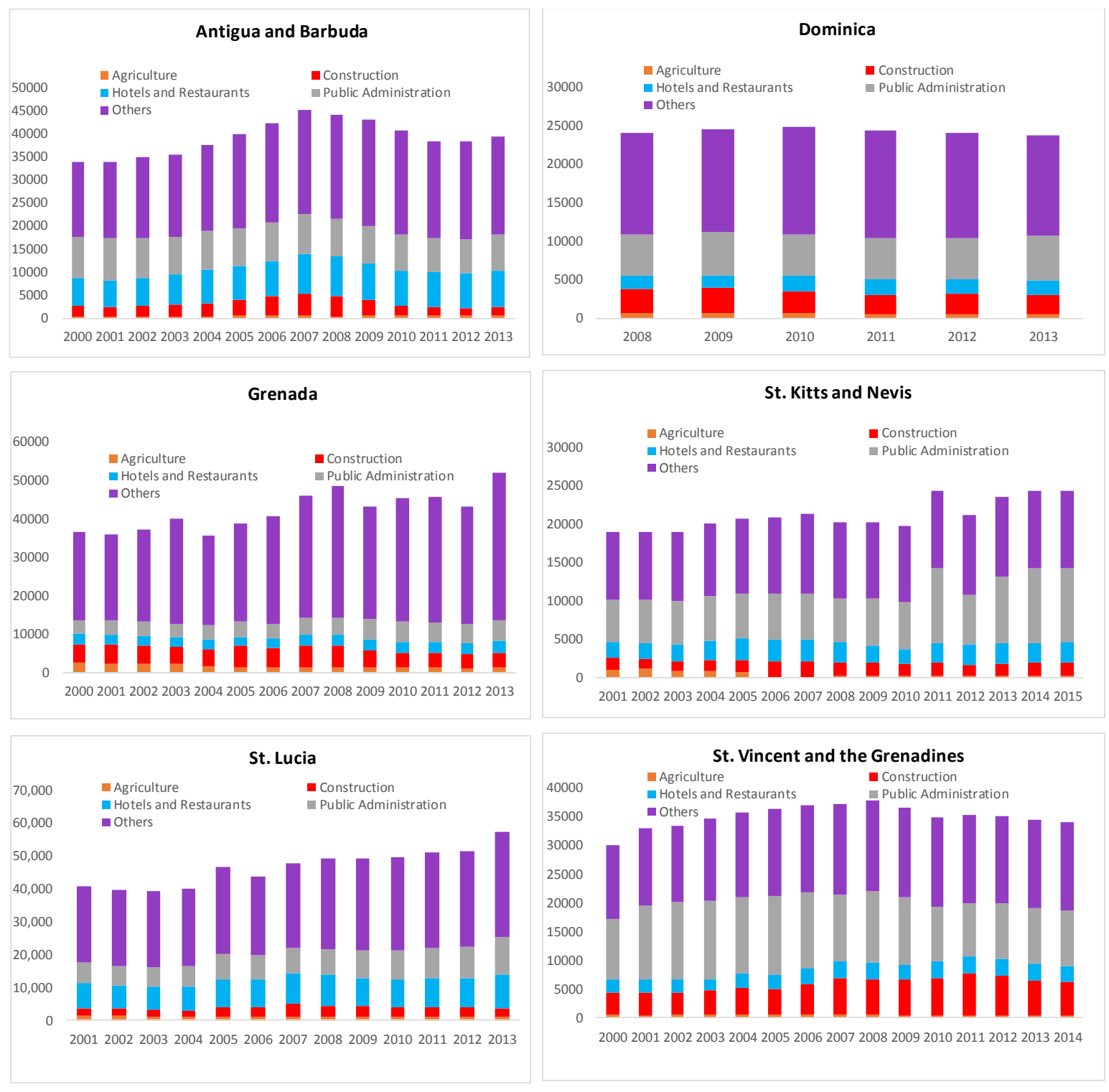

Source: National Insurance Services and IMF Staff calculations. 


\section{Formal Employment in Selected Sectors in ECCU Countries}
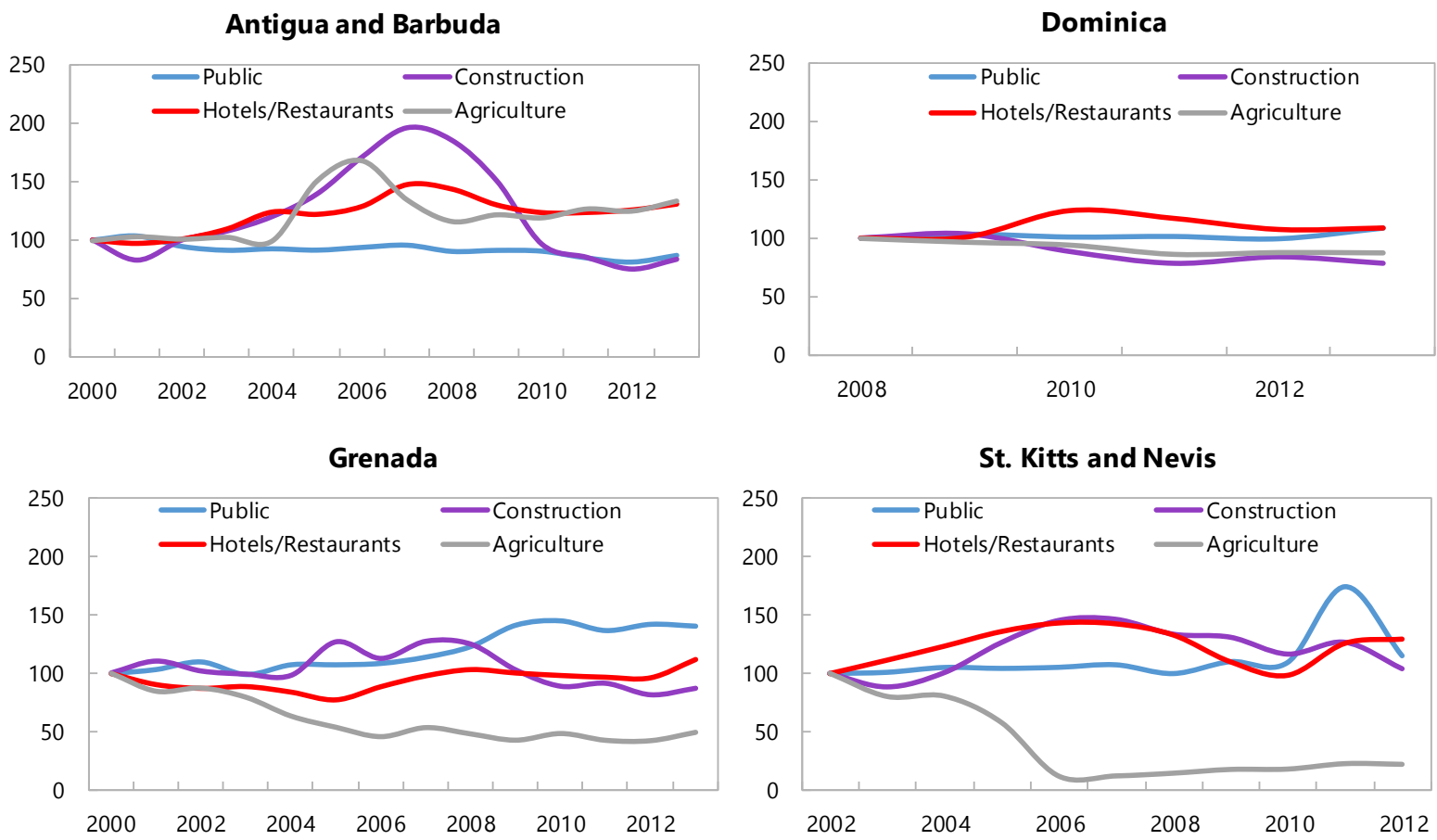

\section{St. Lucia}

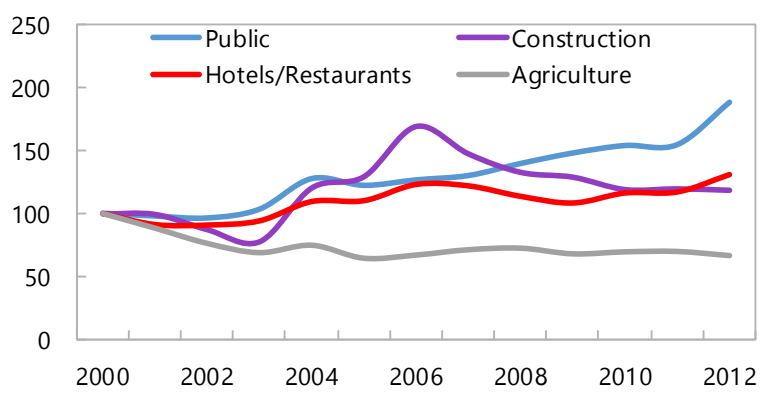

St. Vincent and the Grenadines

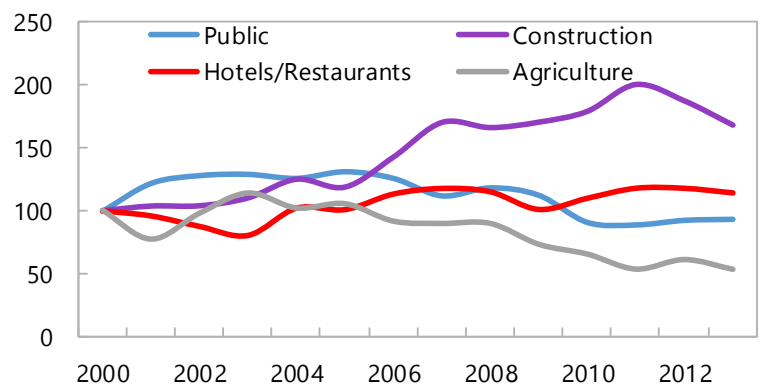

Source: National Insurance Services and IMF staff estimates. 
B. Sectoral demand: the collapse of the banana industry and public sector employment

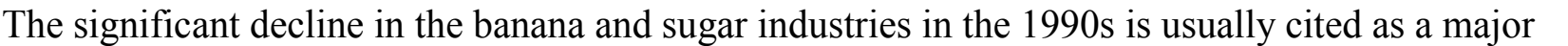

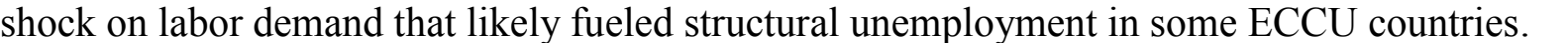

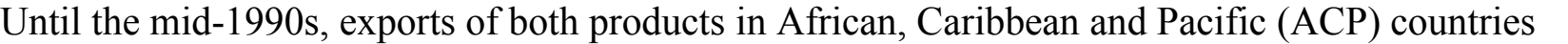

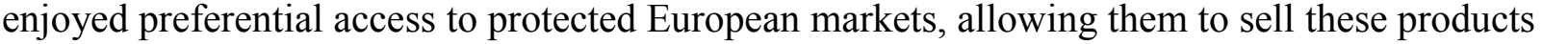

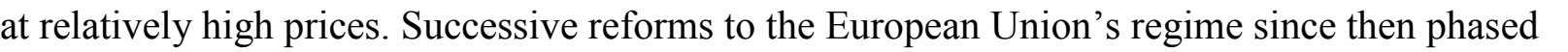

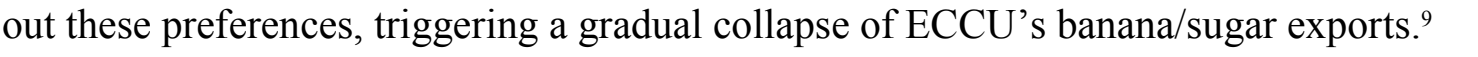

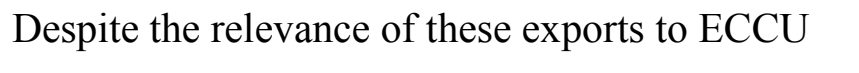

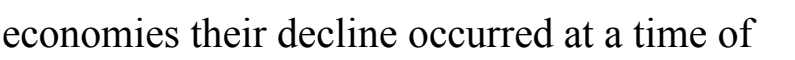

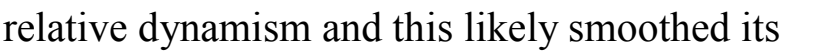

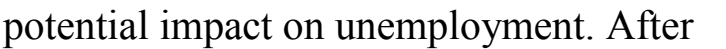

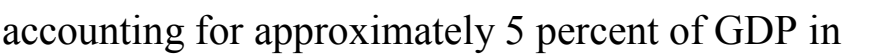

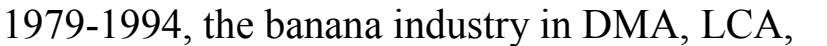

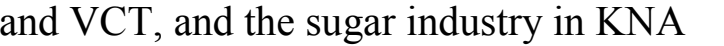

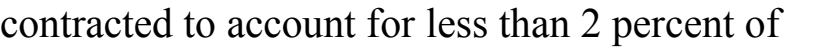

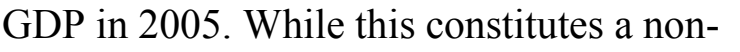

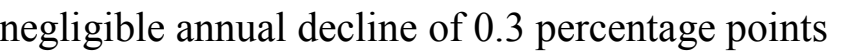

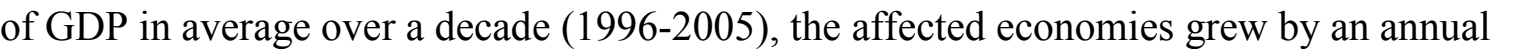

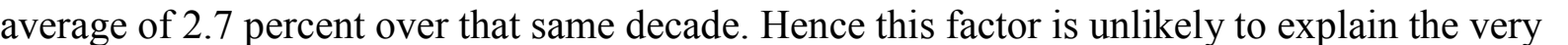

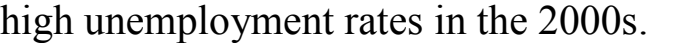
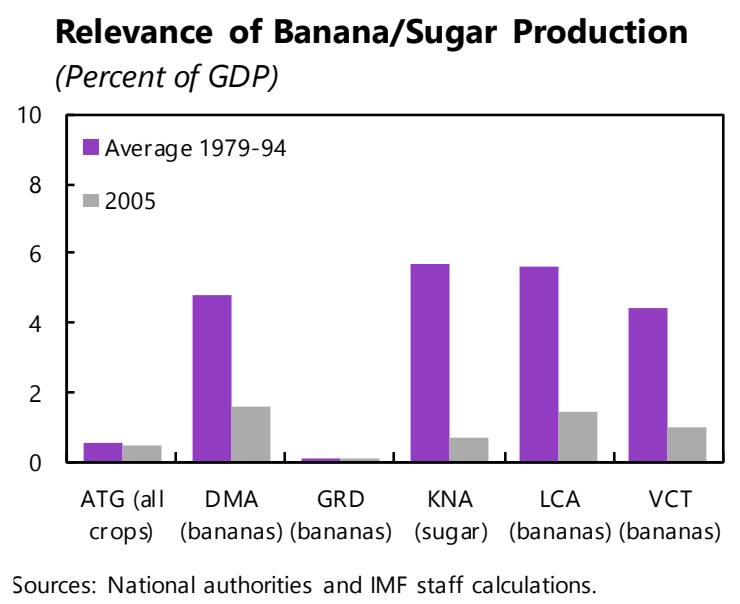

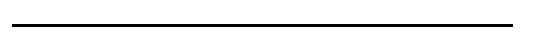

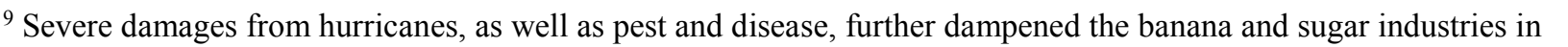

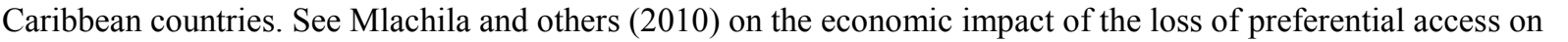




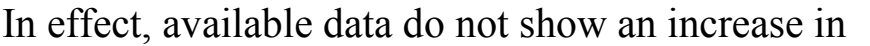

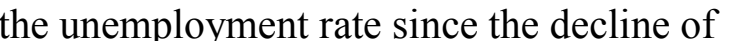

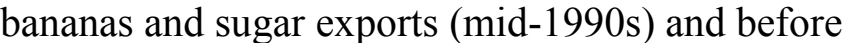

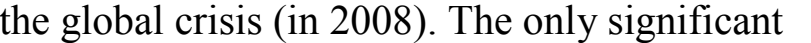

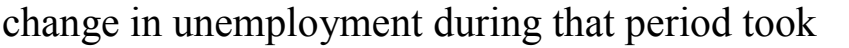

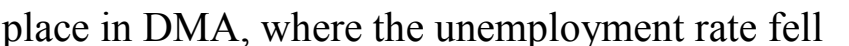

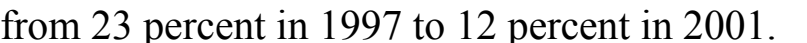

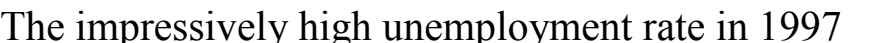

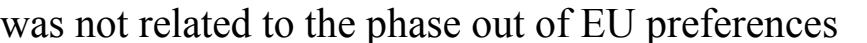

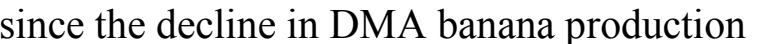

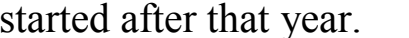

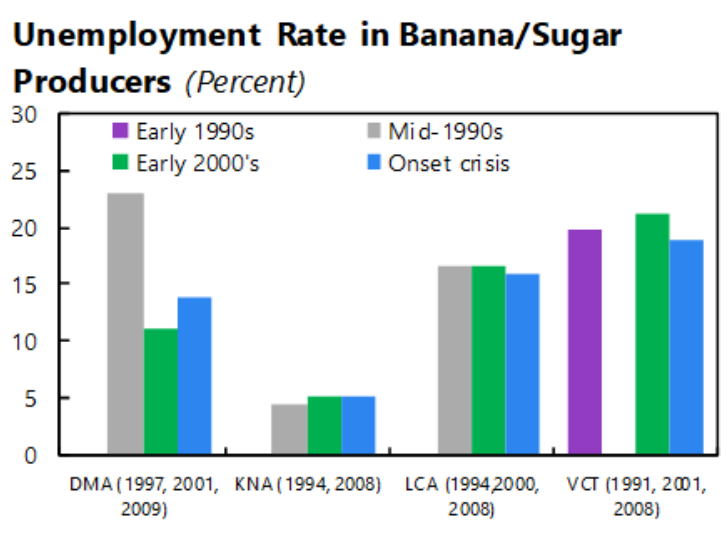

Sources: World Development Indicators database, WB; Youth Unemployment in the Caribbean (year); national authorities; and IMF staff calculations.

\section{$\square \square$ Natural Disasters $\square$}

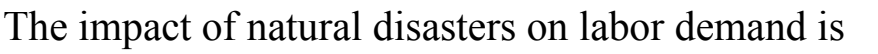
ए

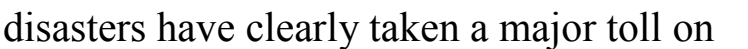

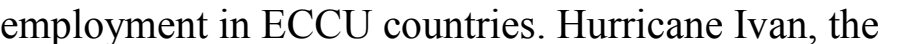

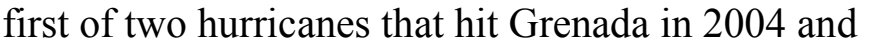

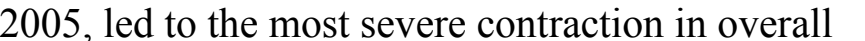

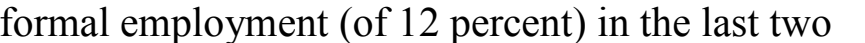

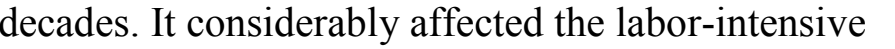
ए ए

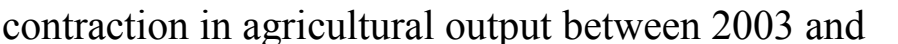

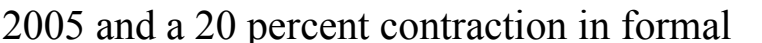

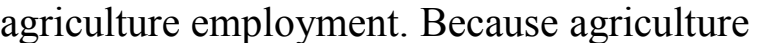

Employment around Natural Disasters (Index equal 100 one yearbefore disaster)

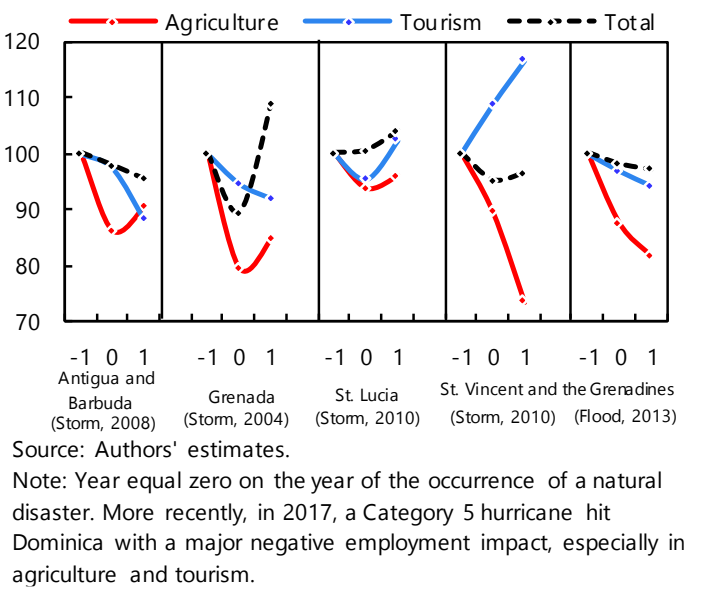

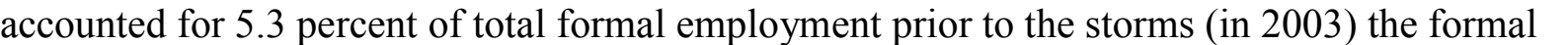

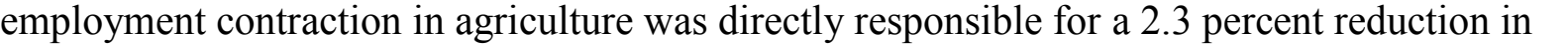

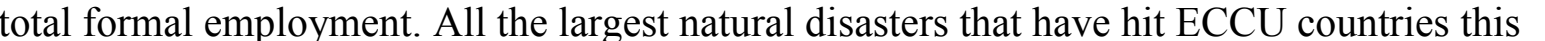

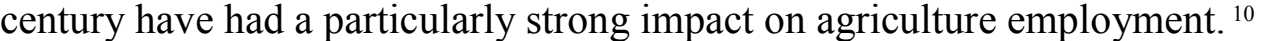

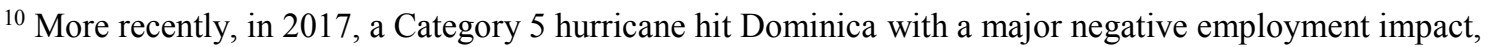

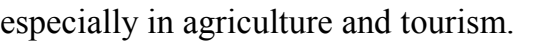




\title{
IV. LABOR SUPPLY: RESERVATION WAGES AND SKILLS MISMATCH
}

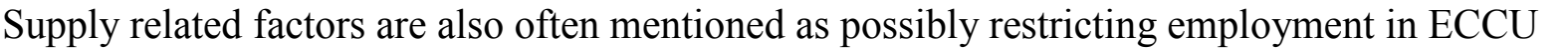

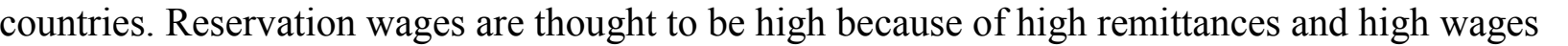

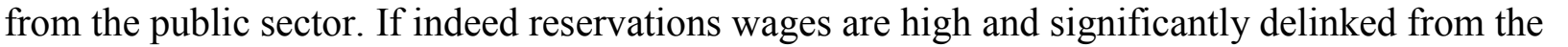

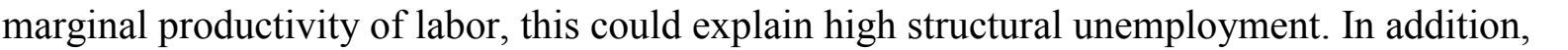

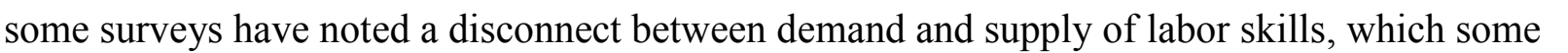

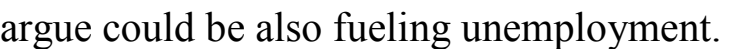

\section{A. Do large remittances lower willingness to work?}

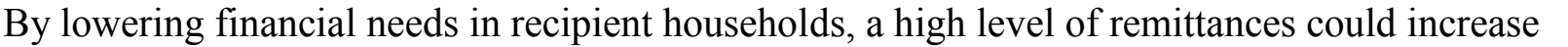

ए

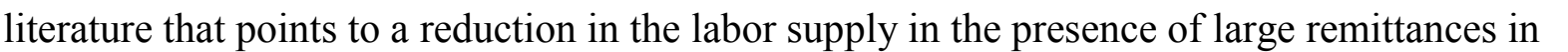

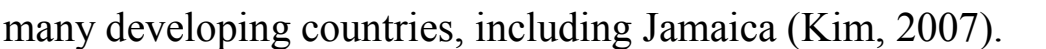

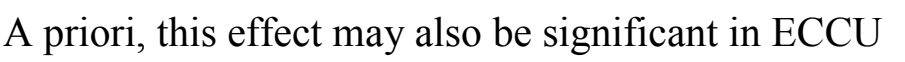

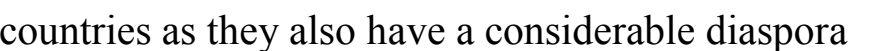

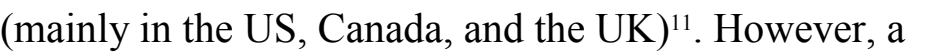

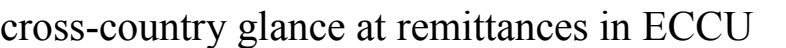

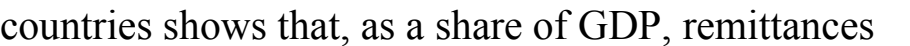

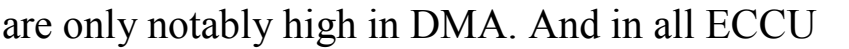

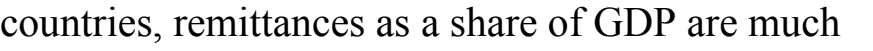

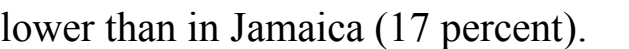

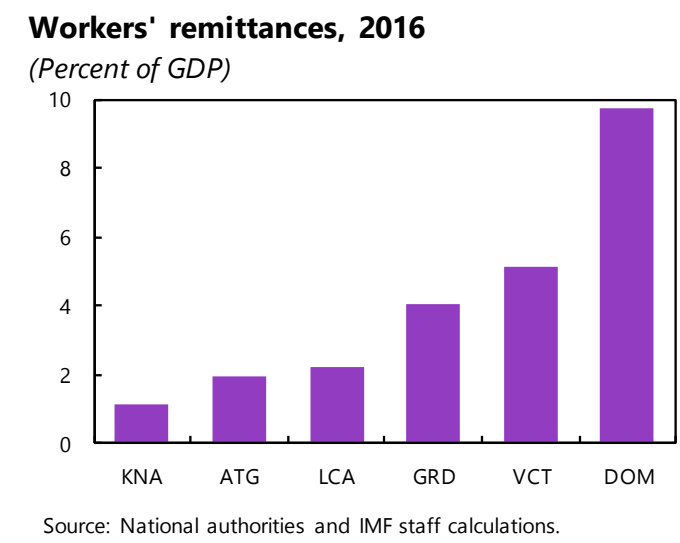

$\square$

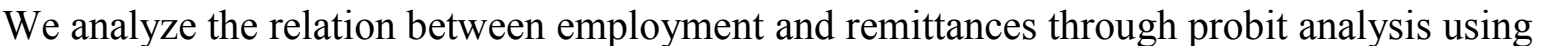
$\square \square \square$ 's 2013, 2014 and 2015 labor force surveys. Our regression includes a dummy signaling

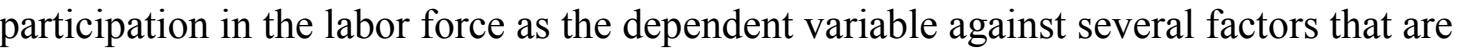

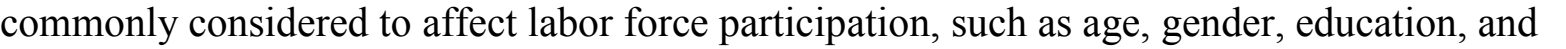

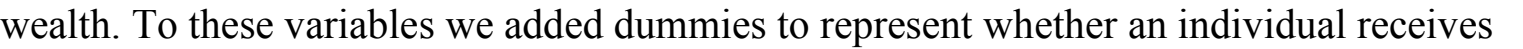

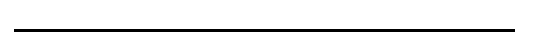

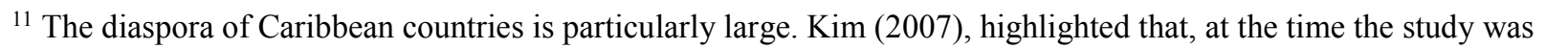

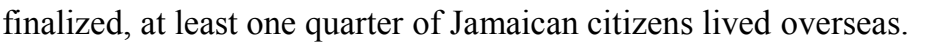

(CInternational Monetary Fund. Not for Redistribution 
Table 1: Probit Regressions: Labor Force Participation Determinants 1/

\begin{tabular}{|c|c|c|}
\hline Dependent Variable: Labor Force Participation & $\begin{array}{c}\text { Overall } \\
\text { Population }\end{array}$ & $\begin{array}{c}\text { Youth } \\
\text { Population }\end{array}$ \\
\hline youth & $\begin{array}{r}-0.708 * * * \\
(0.0485)\end{array}$ & \\
\hline male & $\begin{array}{r}0.345^{* * *} \\
(0.0465)\end{array}$ & $\begin{array}{r}0.269 * * * \\
(0.0733)\end{array}$ \\
\hline secondary and above & $\begin{array}{r}0.802 * * * \\
(0.0486)\end{array}$ & $\begin{array}{r}0.916 * * * \\
(0.0787)\end{array}$ \\
\hline \# of hh mmembers & $\begin{array}{r}0.0271^{* * *} \\
(0.00927)\end{array}$ & $\begin{array}{r}0.0198 \\
(0.0151)\end{array}$ \\
\hline asset index & $\begin{array}{r}-0.0380^{* * *} \\
(0.0134)\end{array}$ & $\begin{array}{r}-0.0682^{* * *} \\
(0.0211)\end{array}$ \\
\hline remittances dummy & $\begin{array}{r}0.0139 \\
(0.0779)\end{array}$ & $\begin{array}{r}0.356^{* *} \\
(0.140)\end{array}$ \\
\hline 2014o.year & $\begin{array}{c}0.127^{* *} \\
(0.0556)\end{array}$ & $\begin{array}{r}0.0760 \\
(0.0894)\end{array}$ \\
\hline 2015.year & $\begin{array}{r}0.102 * \\
(0.0552)\end{array}$ & $\begin{array}{r}0.0413 \\
(0.0884)\end{array}$ \\
\hline $\mathrm{HH}$ head working in public/tourism, secondary education and above & $\begin{array}{c}-0.159 * \\
(0.0813)\end{array}$ & $\begin{array}{r}-0.252 * \\
(0.130)\end{array}$ \\
\hline Constant & $\begin{array}{r}-0.114 \\
(0.0754)\end{array}$ & $\begin{array}{r}-0.764^{* * *} \\
(0.136)\end{array}$ \\
\hline Observations & 3,553 & 1,322 \\
\hline
\end{tabular}




\section{B. Does having a well-paid household member lower willingness to work?}

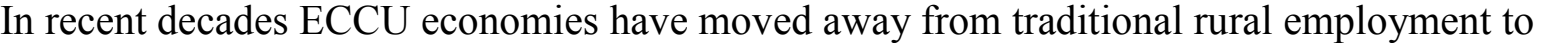

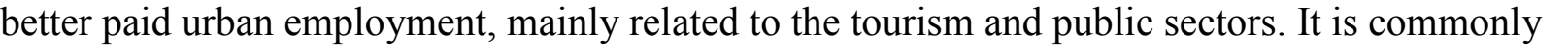

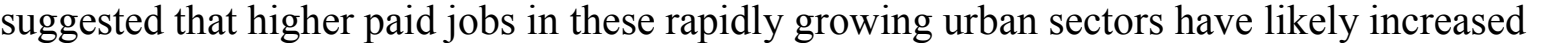

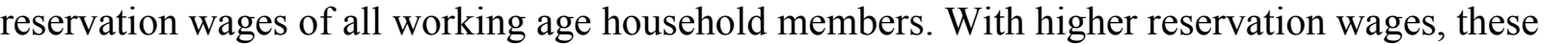

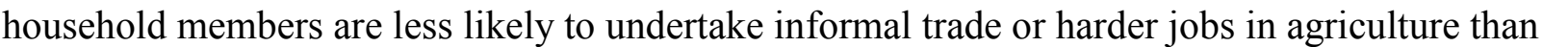

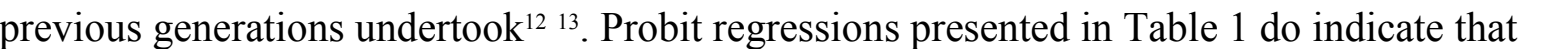

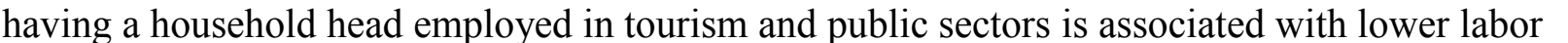

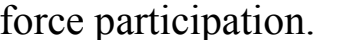

\section{Is there a skills mismatch structurally fueling unemployment?}

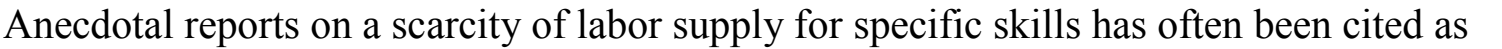

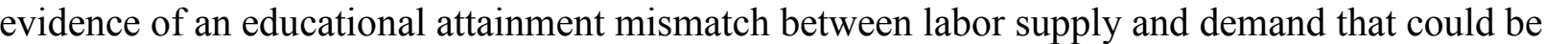

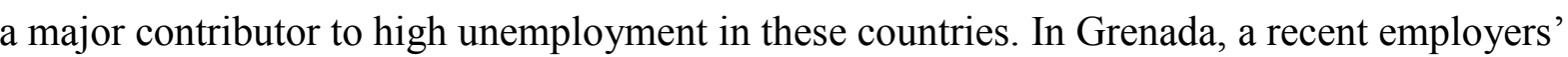

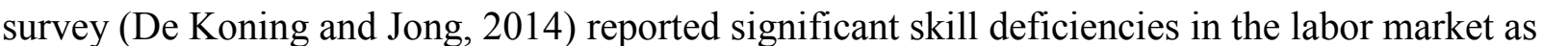

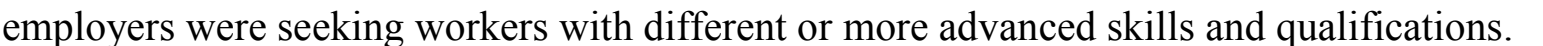

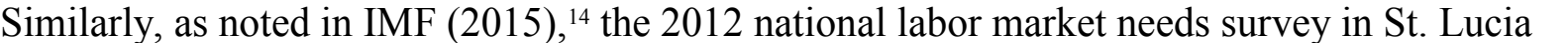

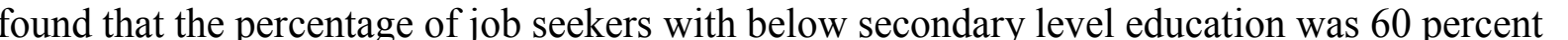

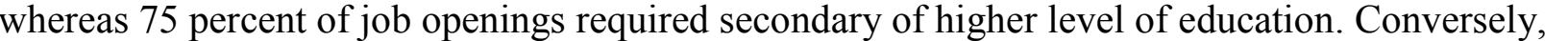

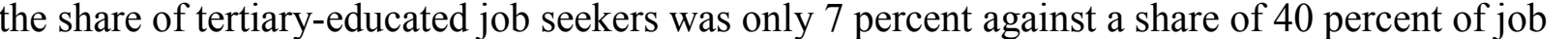
पाणाणाण

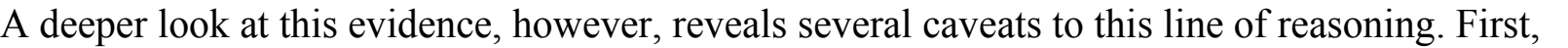

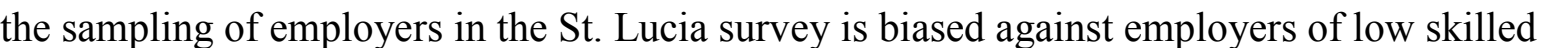

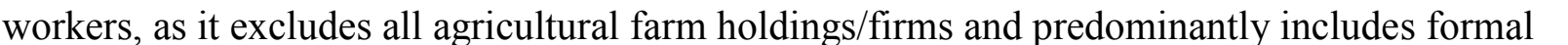

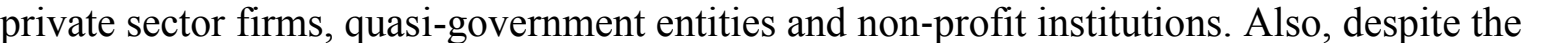

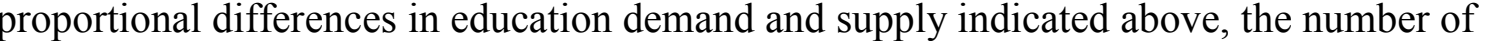

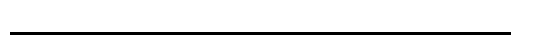

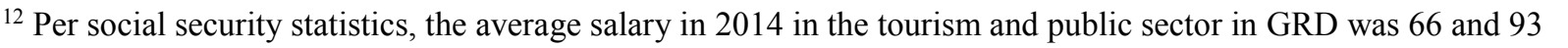

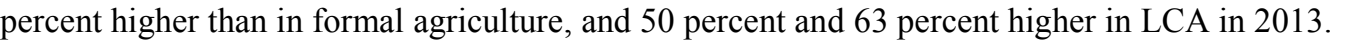

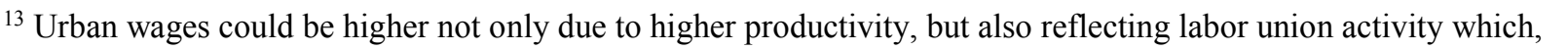
एव

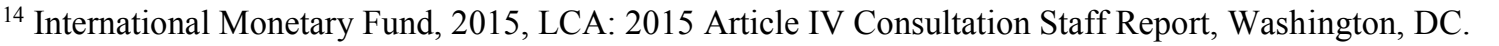




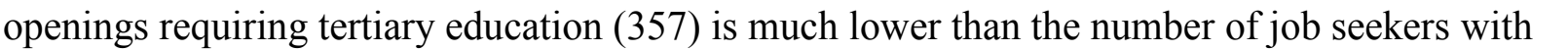

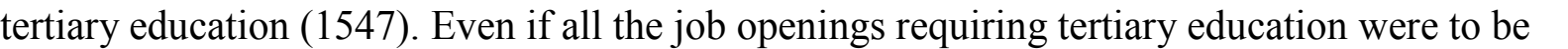
ए पा

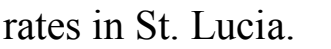

\title{
V. STRUCTURAL RIGIDITIES AND THE ROLE OF GOVERNMENT
}

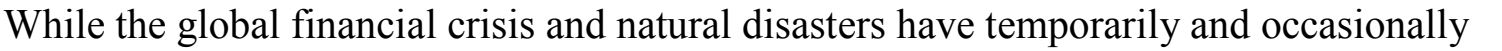

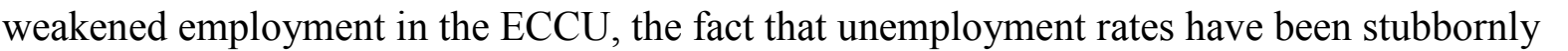

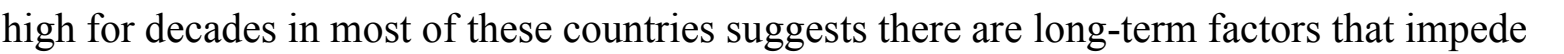 \\ एव

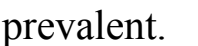

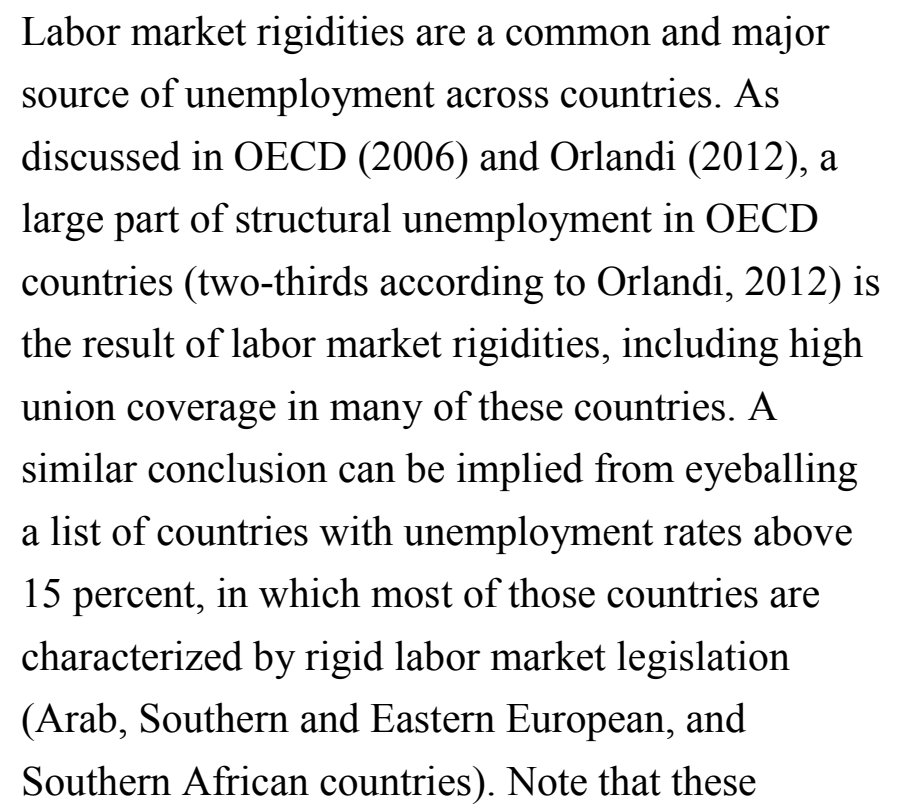

\begin{tabular}{llll}
\multicolumn{4}{l}{ Countries with highest unemployment (2015) } \\
Country & & & \\
& Unemp. & Country & Unemp. \\
\hline & & & \\
Solomon Islands & 31.4 & French Polynesia & 19.3 \\
Gambia, The & 29.6 & Libya & 19.2 \\
Namibia & 26.9 & Gabon & 19.1 \\
Lesotho & 26.5 & VCT & 19.0 \\
Bosnia and Herzegovina & 26.3 & Yemen, Rep. & 18.1 \\
Macedonia, FYR & 26.1 & Botswana & 17.9 \\
West Bank and Gaza & 25.9 & Serbia & 17.7 \\
Swaziland & 25.8 & Montenegro & 17.5 \\
South Africa & 25.1 & Oman & 17.3 \\
Greece & 24.9 & Albania & 17.1 \\
Mozambique & 24.7 & Armenia & 17.0 \\
Grenada & 22.9 & Croatia & 16.3 \\
Spain & 22.1 & Bahamas, The & 16.1 \\
LCA & 20.6 & Iraq & 15.5 \\
Comoros & 19.9 & Tunisia & 15.2 \\
& & & \\
\hline
\end{tabular}

Source: International Labor Organization (ILO Model Estimate) and Grenada's 2015 Labor Force Survey.

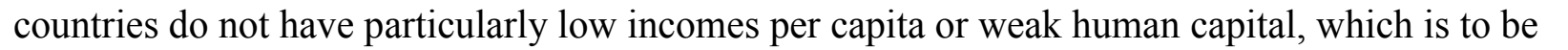

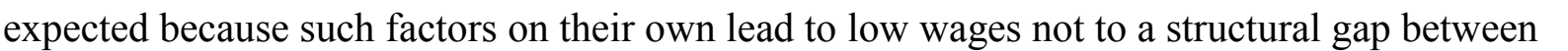

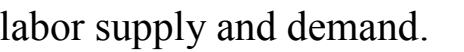

पाm

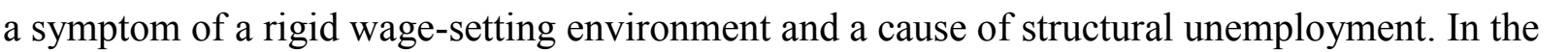

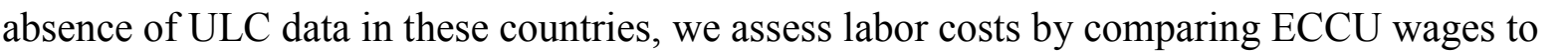




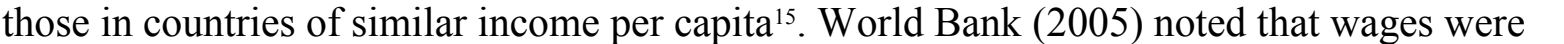

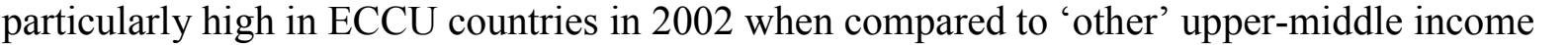

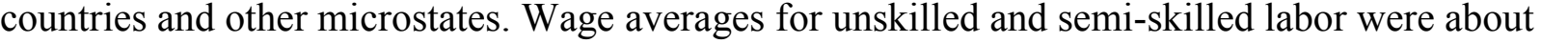

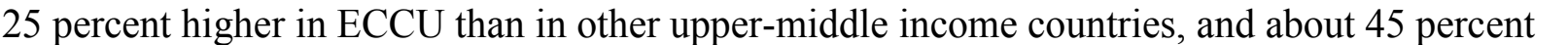

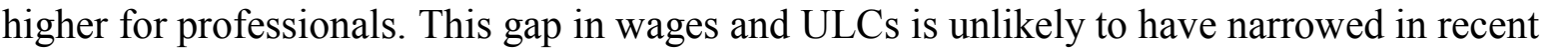

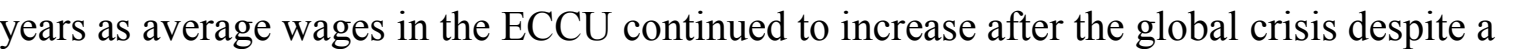

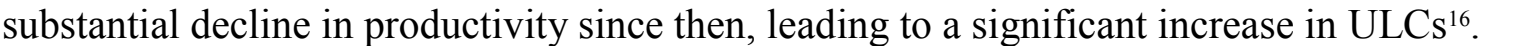

ECCU and Comparator Countries - Selected Wage Rates in 2002 ECCU Average Upper-Middle Microstates Income

Countries

\begin{tabular}{lrrr}
\hline Unskilled (hourly in US\$) & $\mathbf{2 . 3}$ & $\mathbf{1 . 8}$ & $\mathbf{1 . 9}$ \\
$\quad$ Construction worker & 3.5 & 2.0 & 2.0 \\
Clerk in supermarket & 1.8 & 1.8 & 1.9 \\
Kitchen porter & 1.5 & 1.7 & 1.8 \\
& & & \\
Semi-Skilled (annual wage in US\$ thousand) & $\mathbf{7 . 8}$ & 6.3 & $\mathbf{6 . 3}$ \\
Clerk in local bank & 7.8 & 6.2 & 5.7 \\
Clerk in foreign bank & 8.6 & 6.2 & 6.2 \\
Garage mechanic & 7.4 & 6.1 & 6.8 \\
Payroll clerk & 7.5 & 6.7 & 6.6 \\
& & & \\
Professional (annual wage in US\$ thousand) & $\mathbf{2 2 . 3}$ & 15.5 & $\mathbf{1 9 . 0}$ \\
$\quad$ Teacher in public school & 9.8 & 6.9 & 7.2 \\
Manager in local bank & 32.0 & 21.3 & 26.3 \\
Manager in foreign bank & 37.1 & 26.4 & 34.3 \\
Nurse & 10.1 & 7.2 & 8.0 \\
& & & \\
\hline Source: World Bank (2009) & & &
\end{tabular}

Private Wages, Productivity, Unit Labor Cost (3 yr. Moving Average Index, 2001=1001)

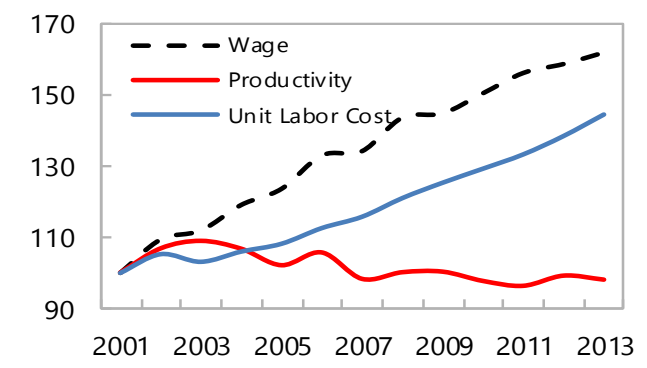

Sources: National Insurance Scheme, national authorities; and IMF staff calculations.

Note: Average for ECCU using data for Antigua and Barbuda, Grenada, St. Lucia, and St. Vincent and the Grenadines during 200213, Dominica 2009-13, and St. Kitts and Nevis 2003-12.

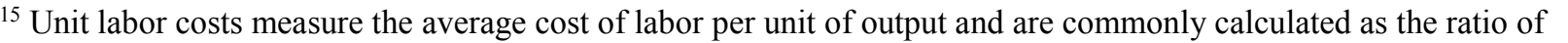
ए

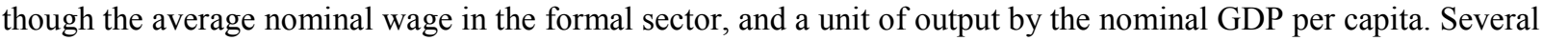

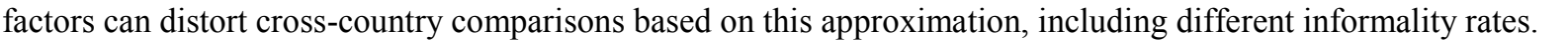

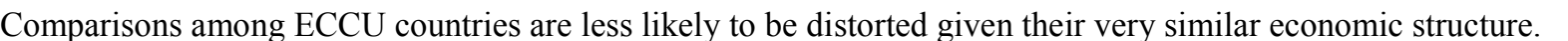

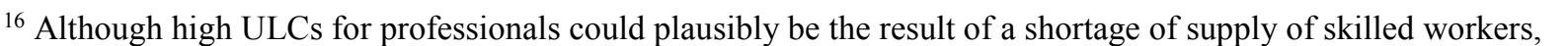

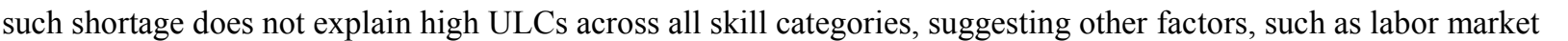

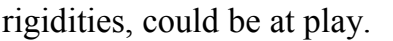




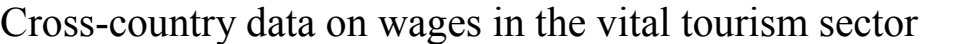

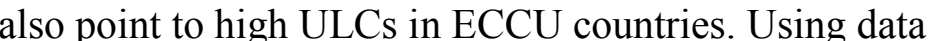

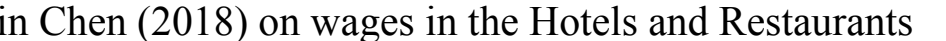

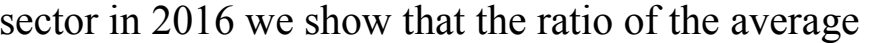

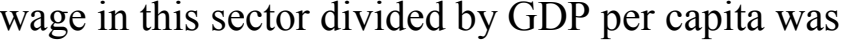

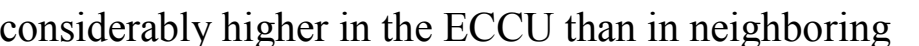

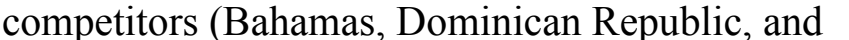

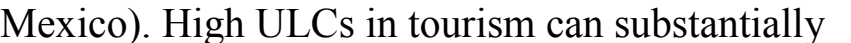

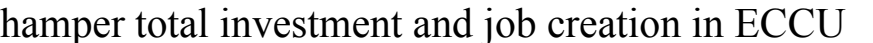

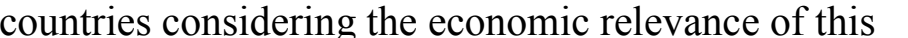

Average Tourism Wages-to-GDP per capita

ECCU and selected tourist countries, 2016)

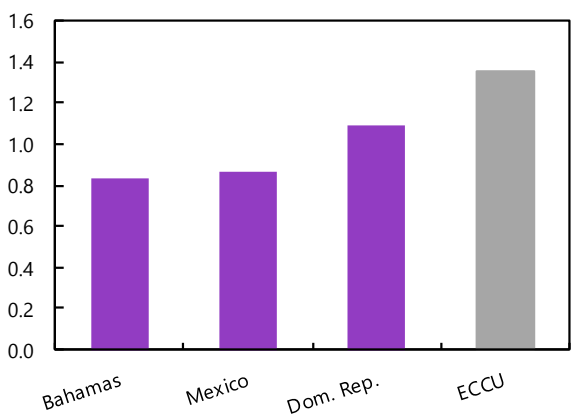

Source: Chen (2018) and authors' calculations

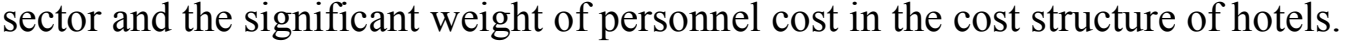

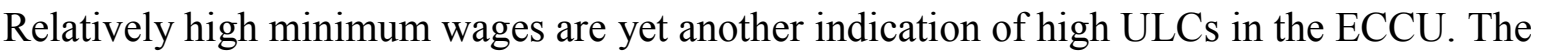

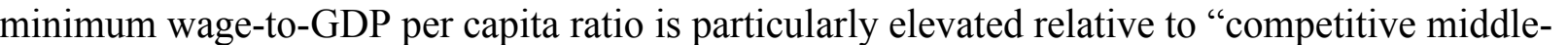
income" countries, those middle income countries that rank in the top 50 of the World Bank's

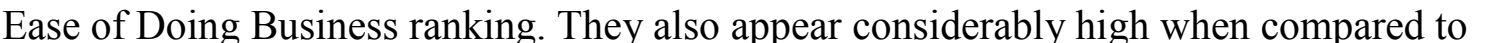
ए।

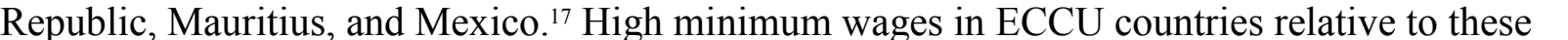

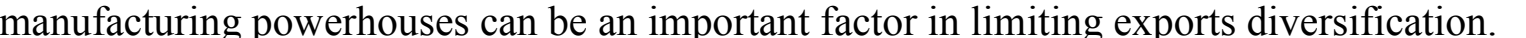

Minimum Wage-to-GDP per Capita Ratio (ECCU and Comparator Country Groups)

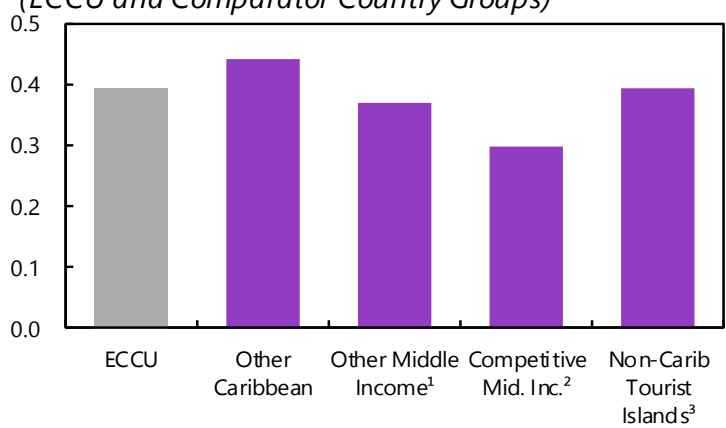

Source: U.S. State Department Reports on Human Rights Practices University of Amsterdam Wage Indicator Foundation, and national authorities.
Minimum Wage-to-GDP per Capita Ratio

(ECCU and Selected Tourism/Manufacturing Countries)

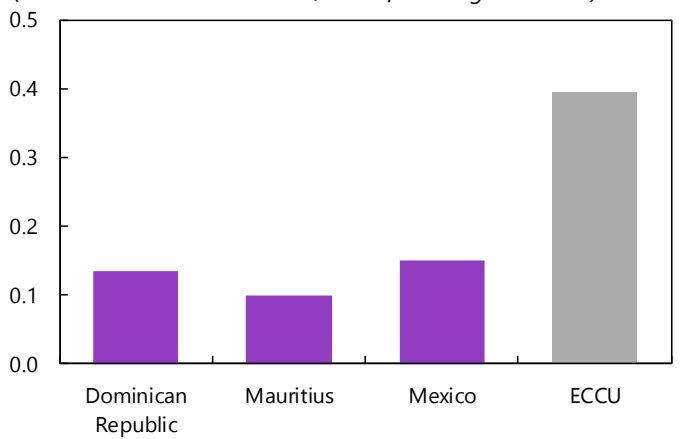

Source: U.S. State Department Reports on Human Rights Practices, University of Amsterdam Wage Indicator Foundation, and national authorities.

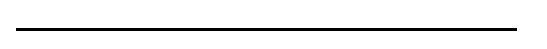

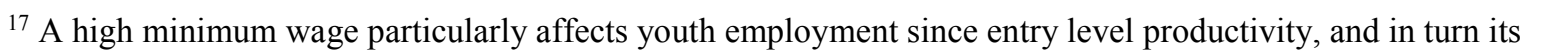

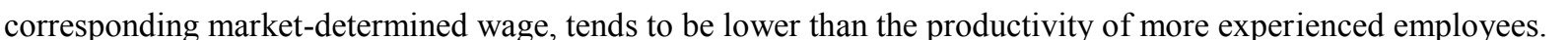

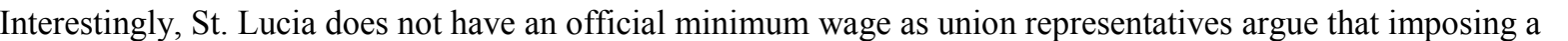

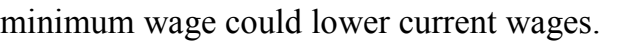




\section{A. High Unit Labor Costs and Unemployment}

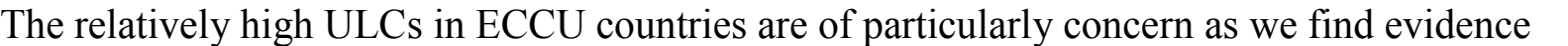
पा ए

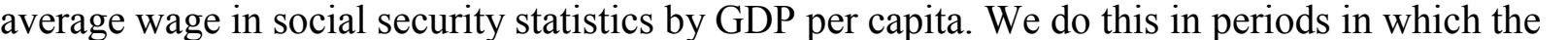

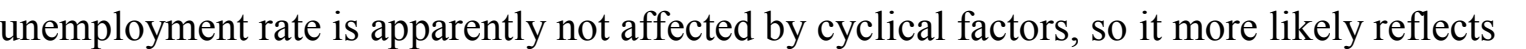

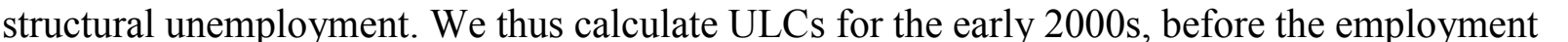

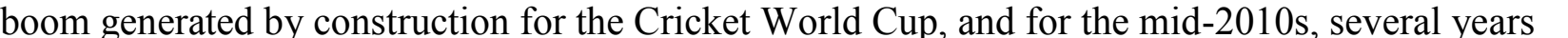

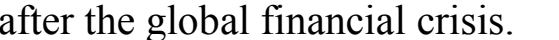

पाm

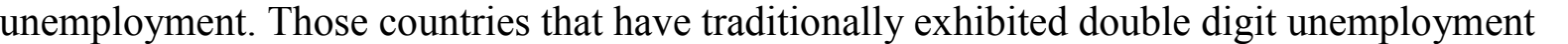

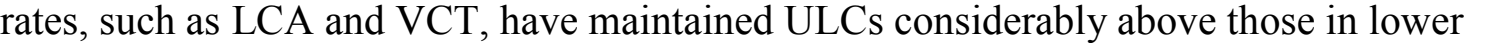

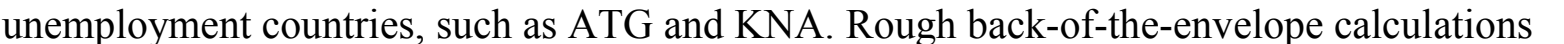

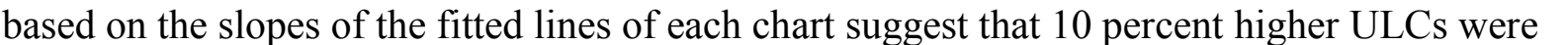

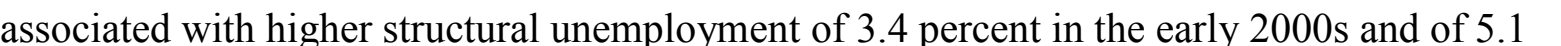

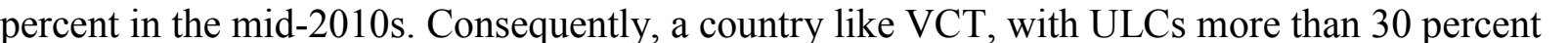

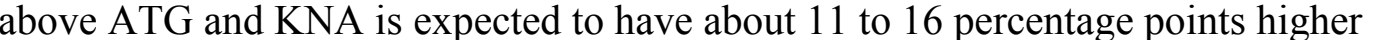

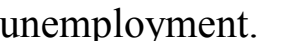

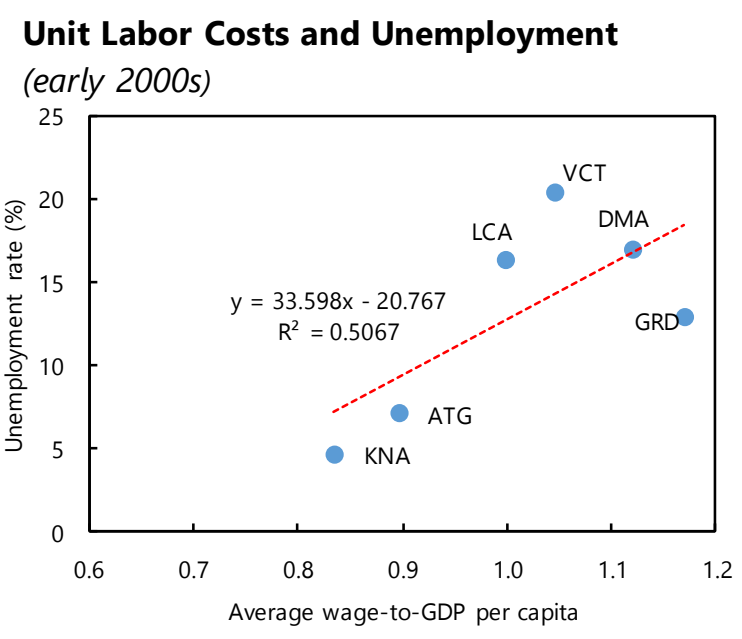

Source: National insurance schemes and IMF staff calculations.

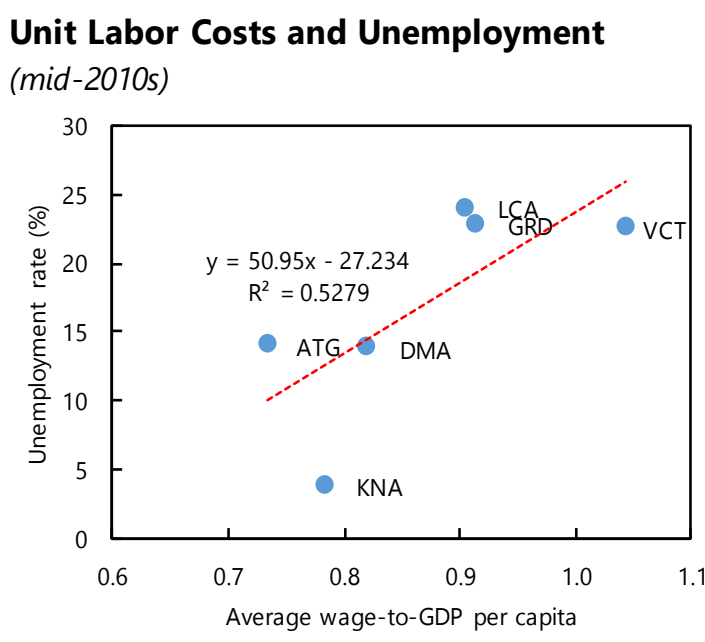

Source: National insurance schemes and IMF staff calculations.
एा

$\square$

$\square$

$\square$

$\square$

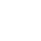

$\square$

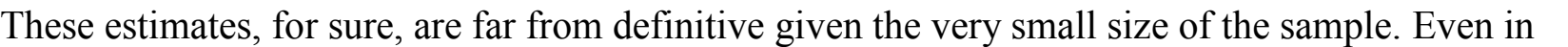

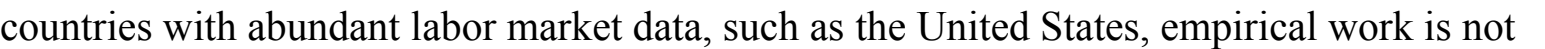

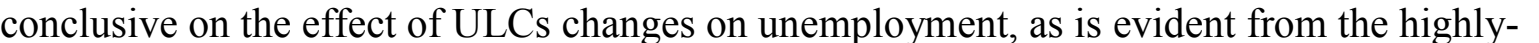

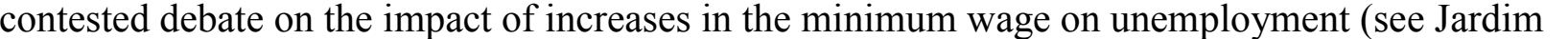




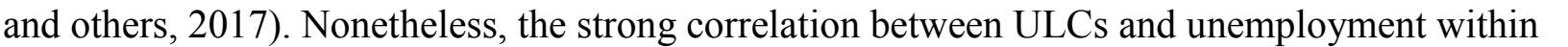
ए

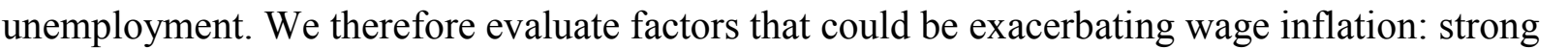

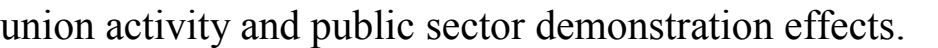

\section{B. Strong union activity in the wage setting process}

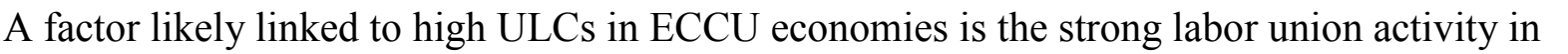

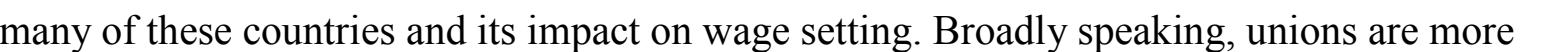

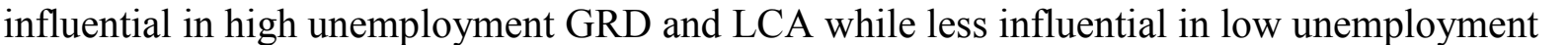
$\square \square \square^{18} \square$

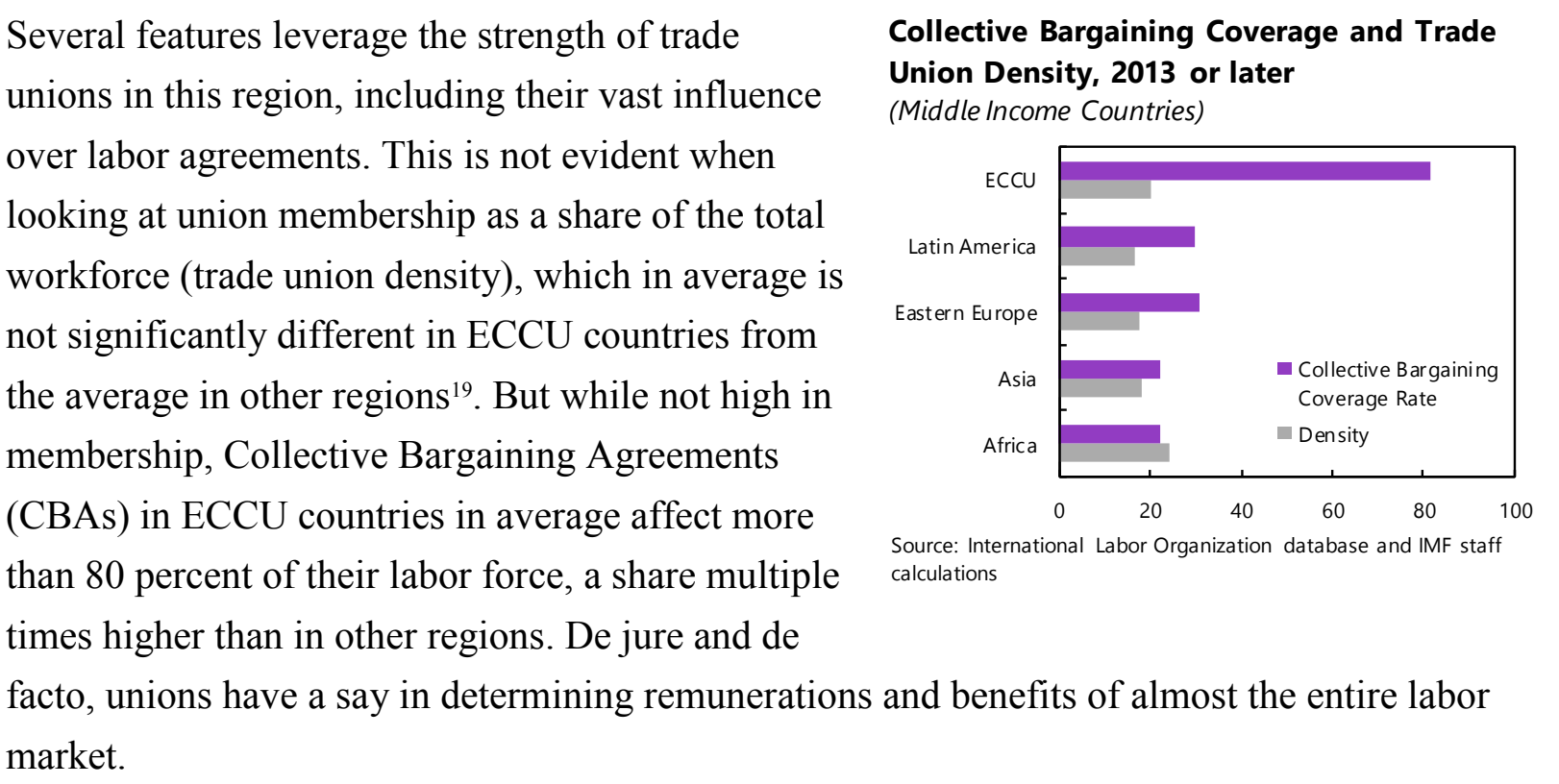

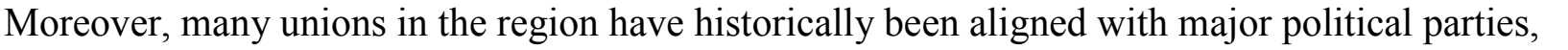

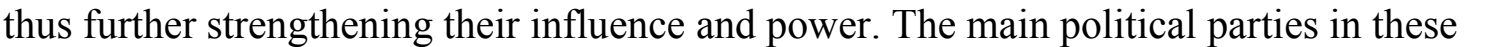

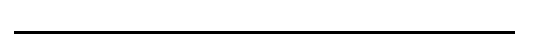

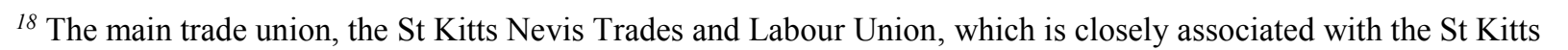

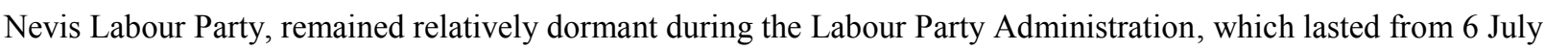

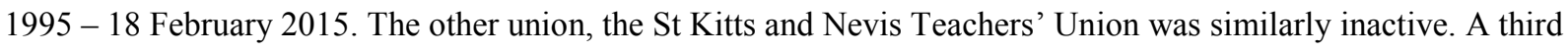

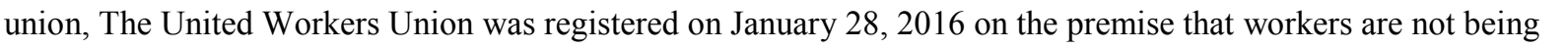

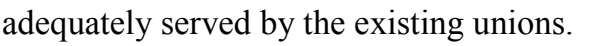

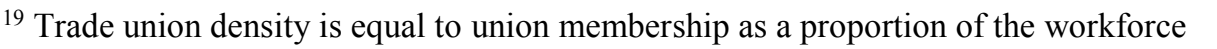

(continued...) $\square$ 


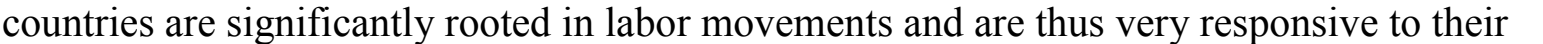

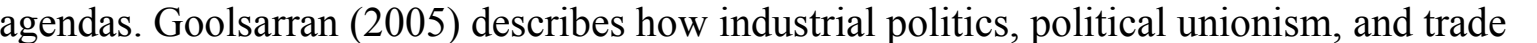

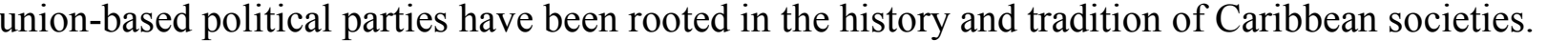

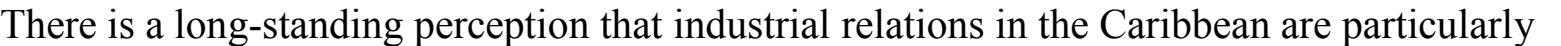

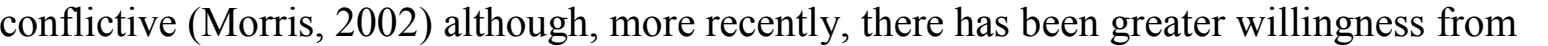

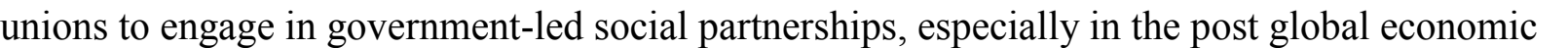

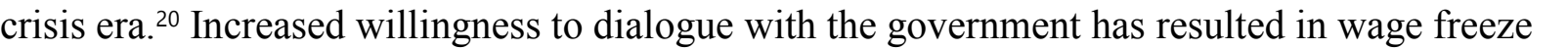

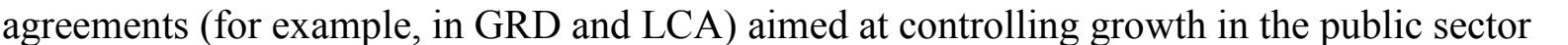

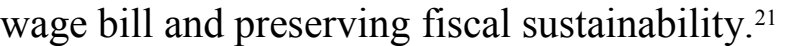

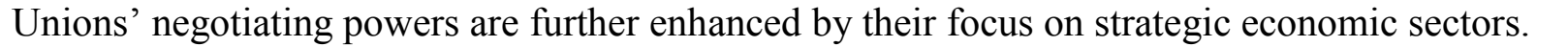

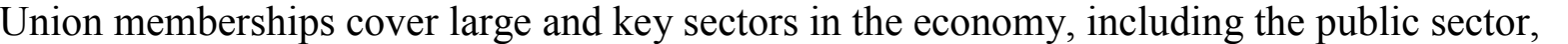

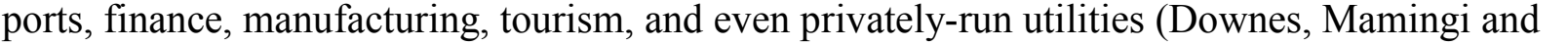

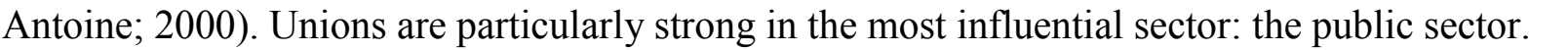

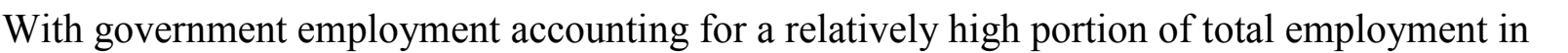

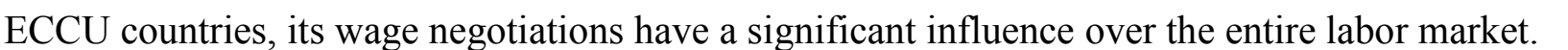

$\square$

$\square$

$\square$

$\square$ m

${ }^{20}$

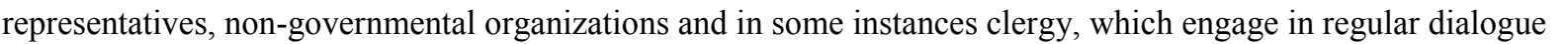

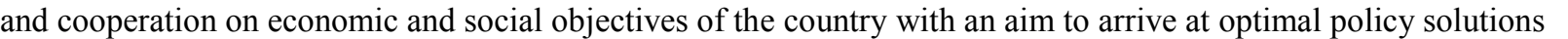

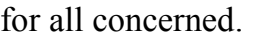

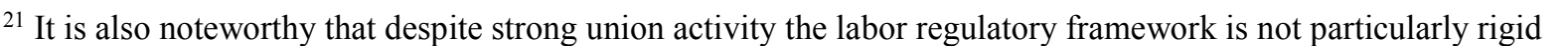
एण

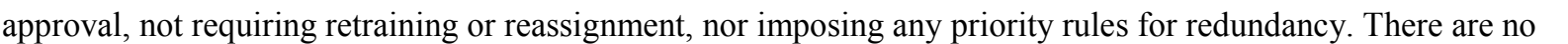

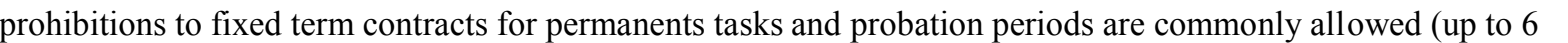

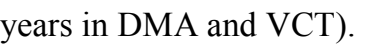


C. Public sector wage demonstration effects

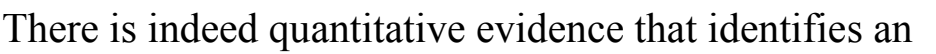

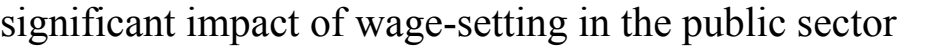

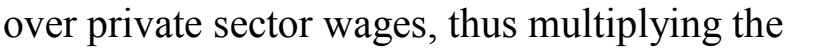

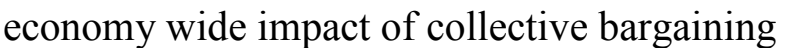

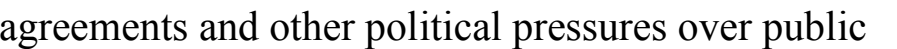

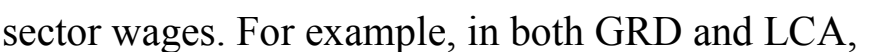

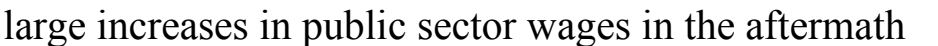

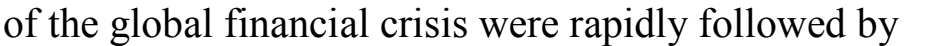

ए

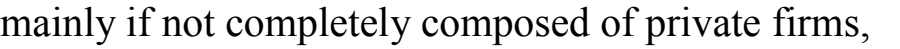

1 S

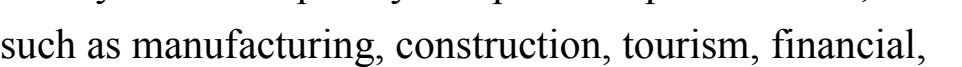

Nominal Public and Private Sector Wages in Grenada and St. Lucia (Index, 2008=100)

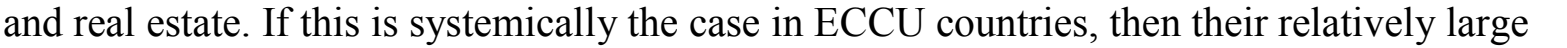

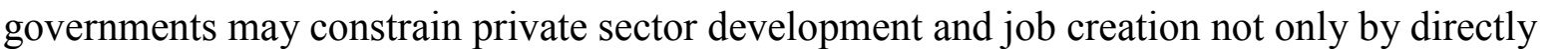

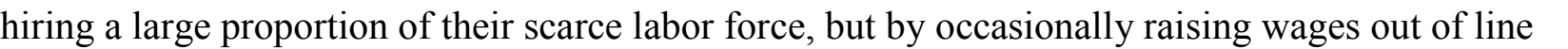

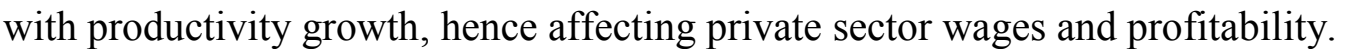

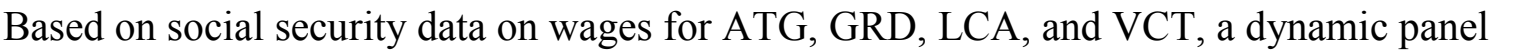

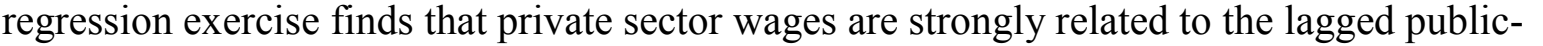

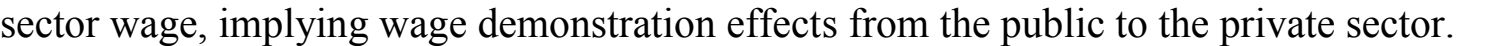

ए

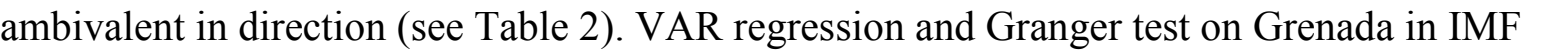

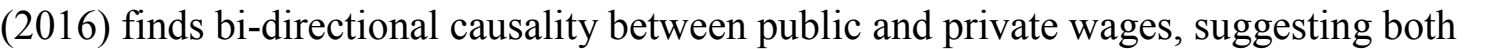

"signaling" and "competition" effects between the two sectors. $\square$

CInternational Monetary Fund. Not for Redistribution 
ECCU Countries - Regressing Private Sector Wages on Lagged Public Sector Wages and Other Determinants

OLS Random Effects Fixed Effects Difference GMM System GMM

Dependent Variable: Private Sector Real Wage

\begin{tabular}{|c|c|c|c|c|c|}
\hline \multirow[t]{2}{*}{ Lagged Private Sector Wage } & 0.056 & 0.056 & 0.041 & 0.031 & $0.138^{*}$ \\
\hline & $(0.28)$ & $(0.27)$ & $(0.02)$ & $(0.02)$ & $(0.05)$ \\
\hline \multirow[t]{2}{*}{ Lagged Public Sector Wage } & $0.934 * * *$ & $0.934 * * *$ & $0.585^{* * *}$ & $0.580^{* * *}$ & $0.820 * * *$ \\
\hline & $(0.00)$ & $(0.00)$ & $(0.25)$ & $(0.31)$ & $(0.00)$ \\
\hline \multirow[t]{2}{*}{ Lagged CPI } & -0.073 & -0.073 & $0.382^{*}$ & 0.405 & 0.037 \\
\hline & $(-0.08)$ & $(-0.07)$ & $(0.01)$ & $(0.01)$ & (0.43) \\
\hline \multirow[t]{2}{*}{ Lagged Productivity } & 0.04 & 0.04 & -0.038 & -0.01 & 0.106 \\
\hline & $(0.36)$ & $(0.36)$ & $(-0.05)$ & $(-0.09)$ & (0.92) \\
\hline \multirow[t]{2}{*}{ Constant } & 0.263 & 0.263 & 1.411 & 1.296 & -0.307 \\
\hline & $(0.57)$ & $(0.56)$ & $(0.05)$ & $(0.11)$ & $(-0.66)$ \\
\hline Observations & 66 & 66 & 66 & 61 & 66 \\
\hline
\end{tabular}

\section{CONCLUSIONS AND POLICY RECOMMENDATIONS}

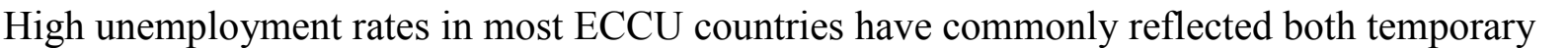

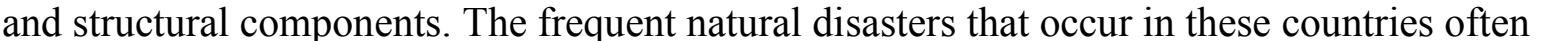

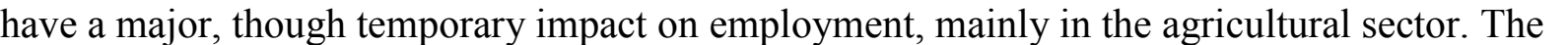

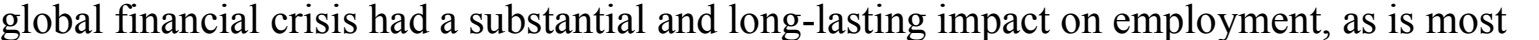

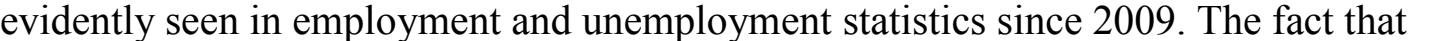

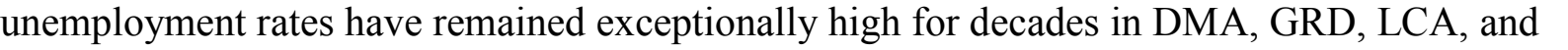

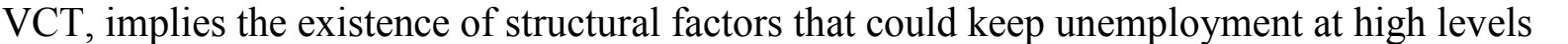

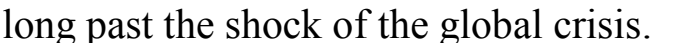

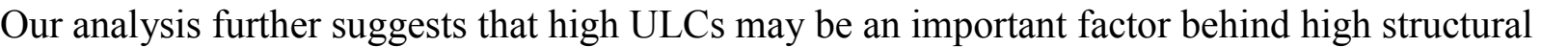

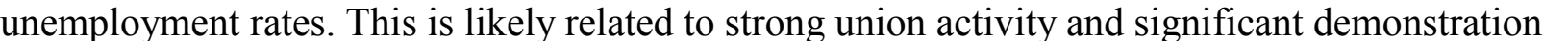

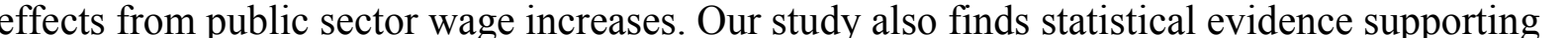

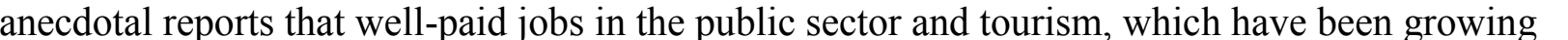

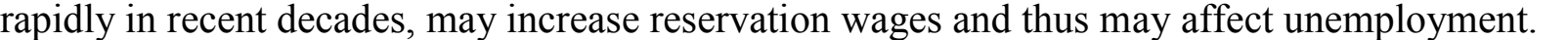

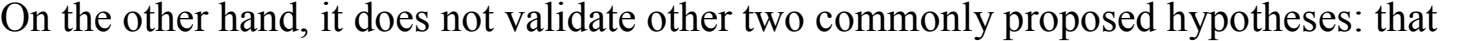

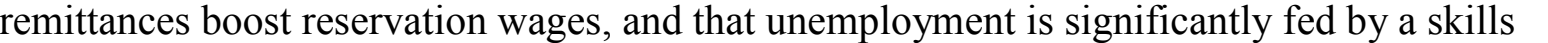

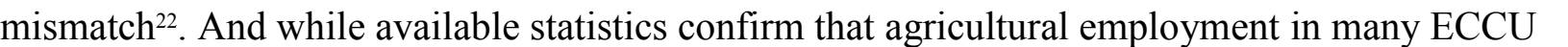

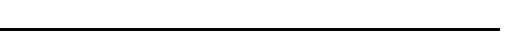

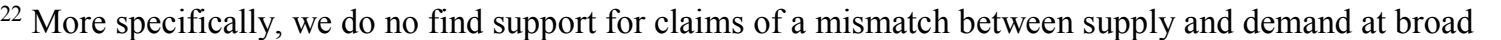

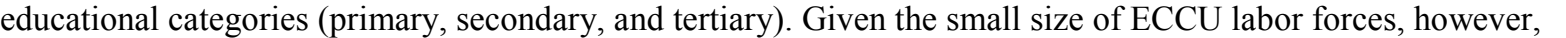

(continued...) $\square$ 


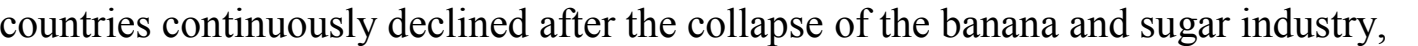

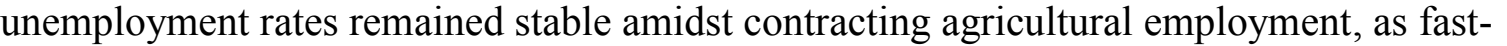

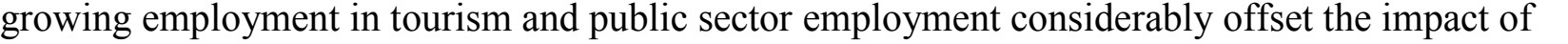

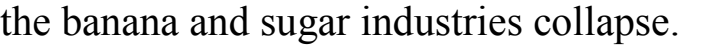

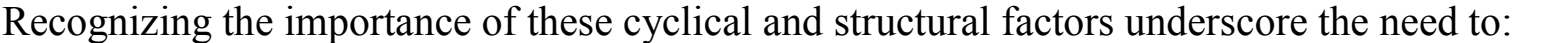

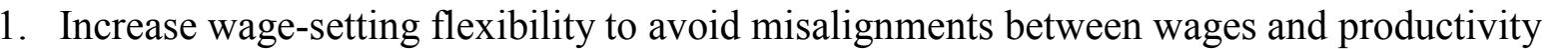

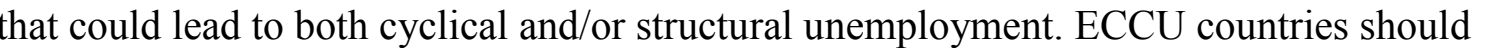

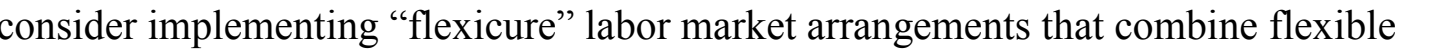

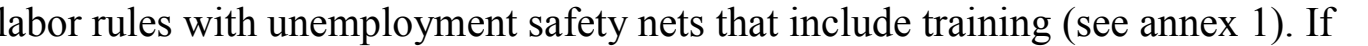

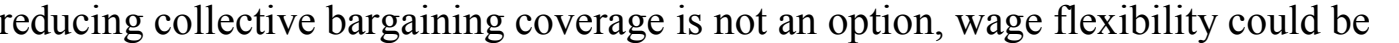

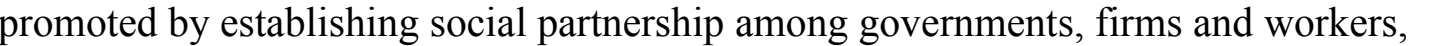

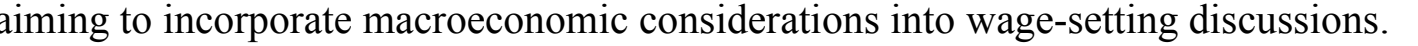

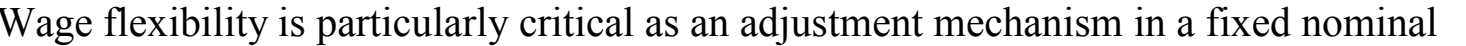

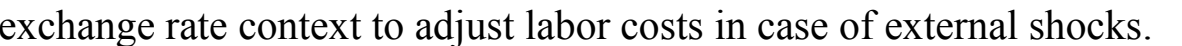

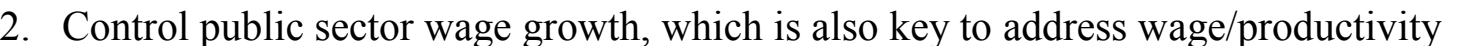

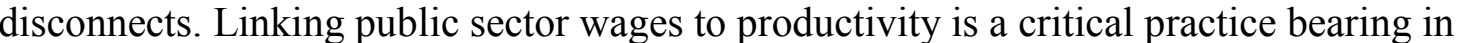

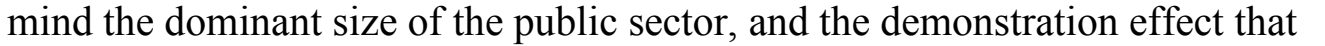

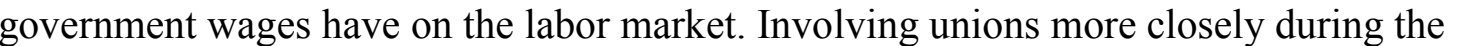

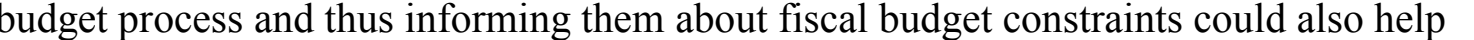

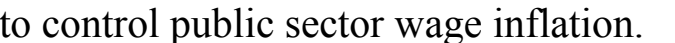

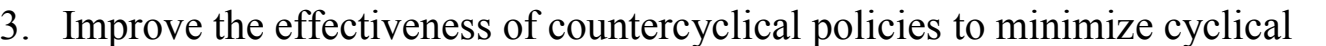

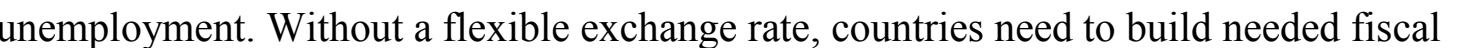

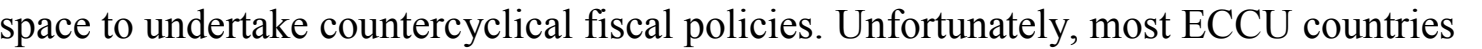

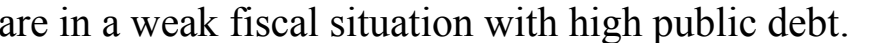

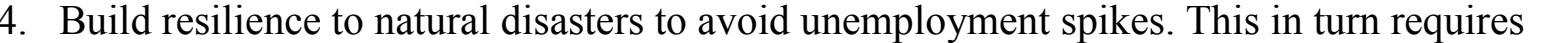

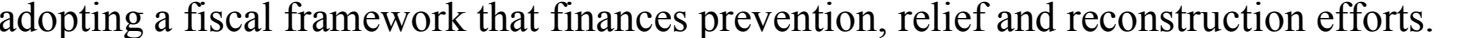

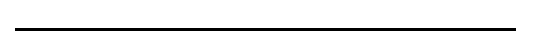

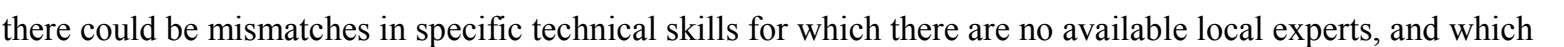

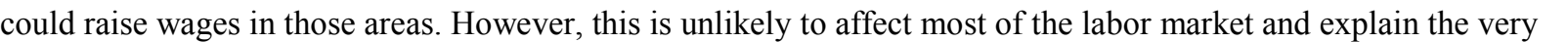

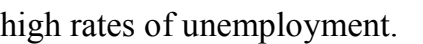




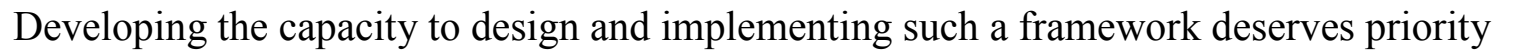

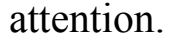

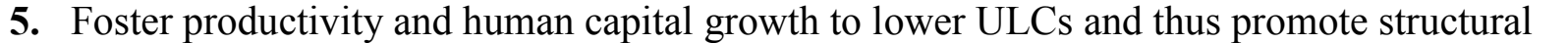

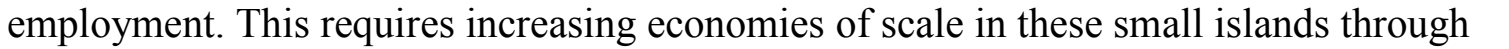

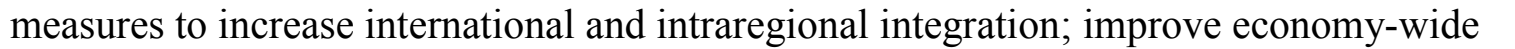

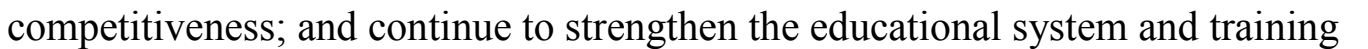

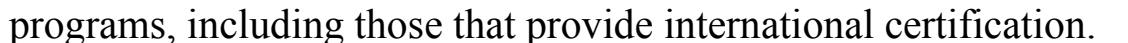

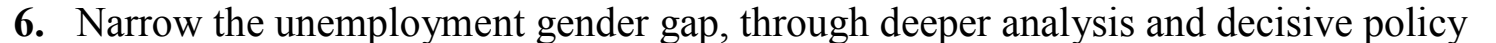

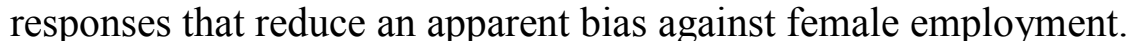


References

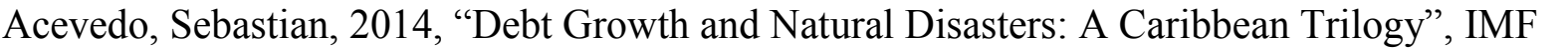

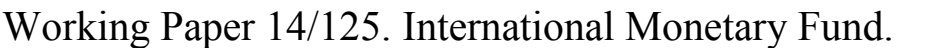

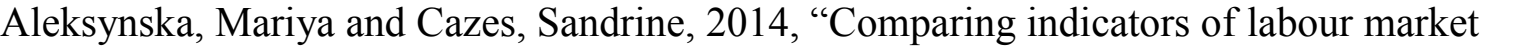

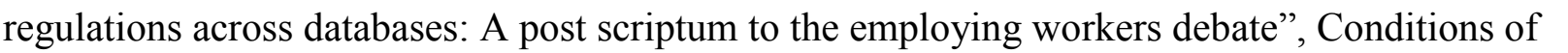

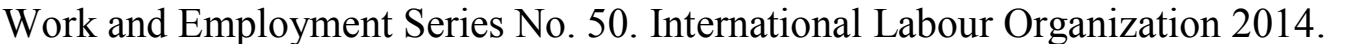

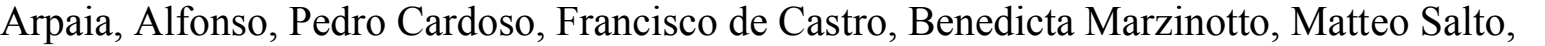

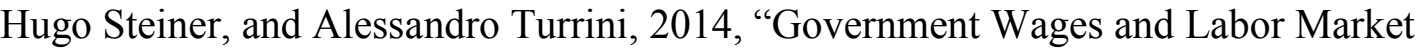

Outcomes”, European Commission Economic and Financial Affairs Occasional Paper 190.

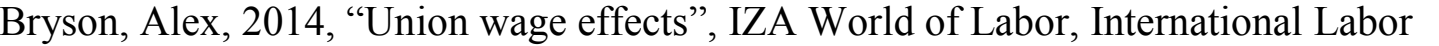

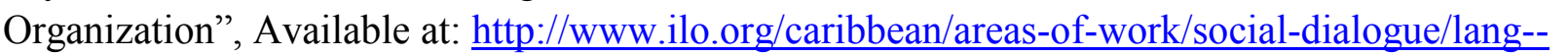

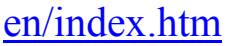

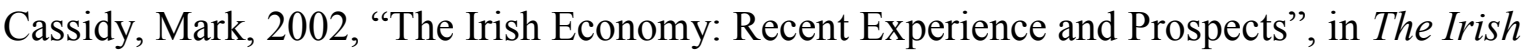

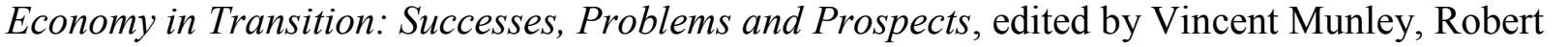

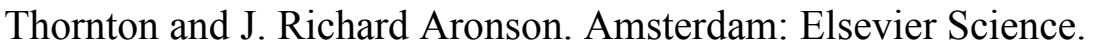

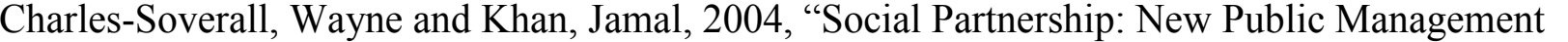

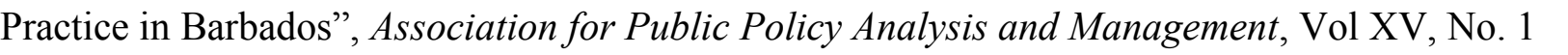

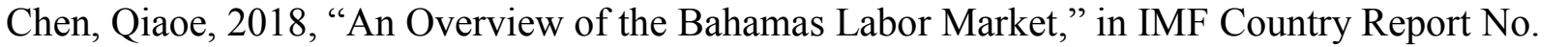

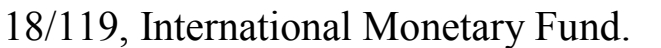

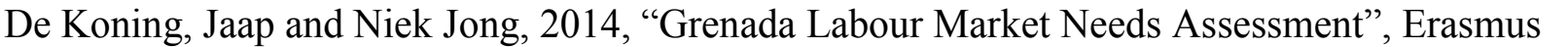

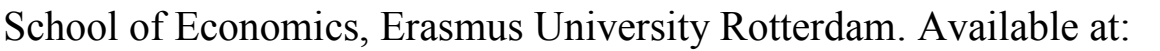

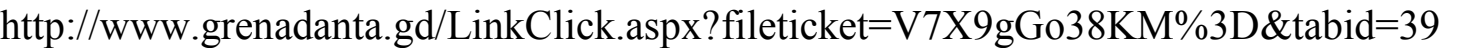

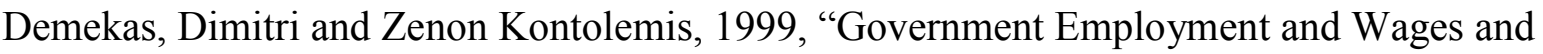

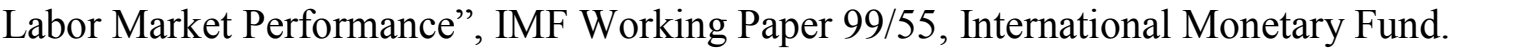

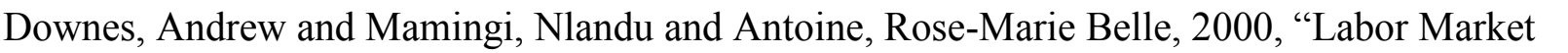

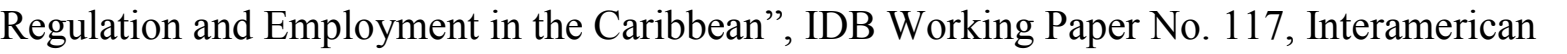

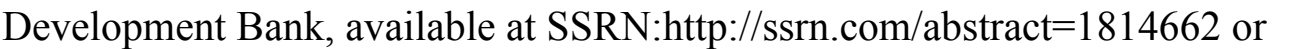

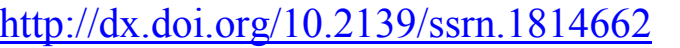

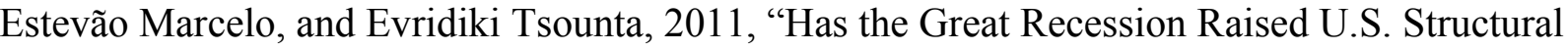
Unemployment?" 


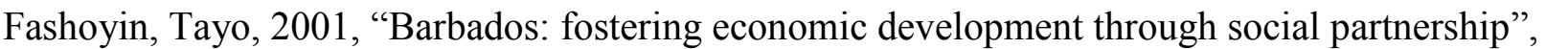

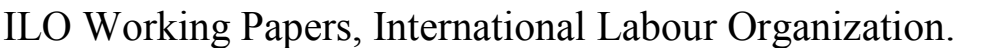

Gimenez, Leo, Edwin St. Catherine, Jonathan Karver, and Rei Odawara, 2015, "The Aftermath

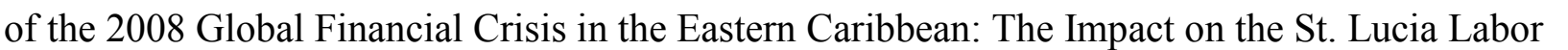

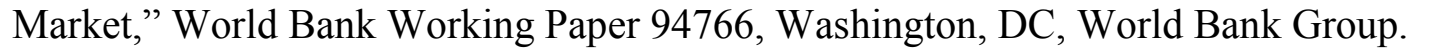

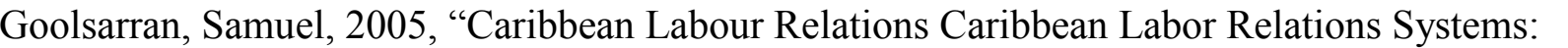

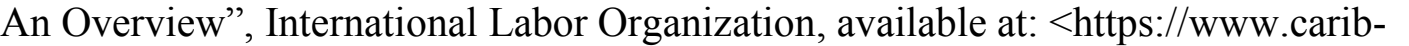

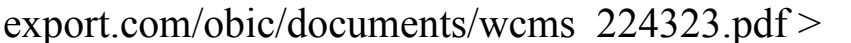

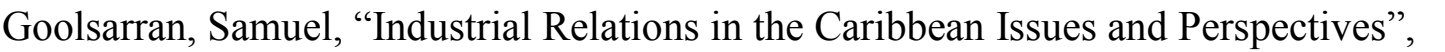

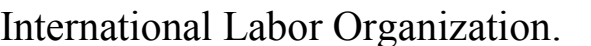

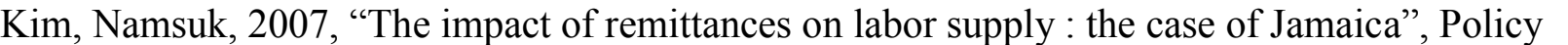

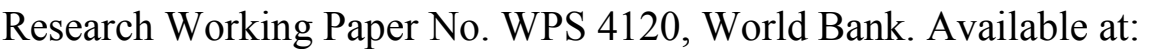

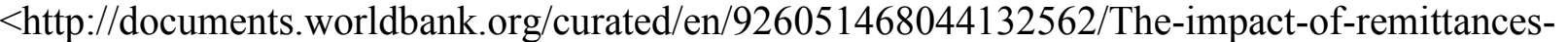

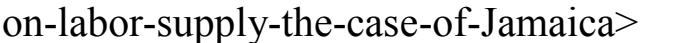

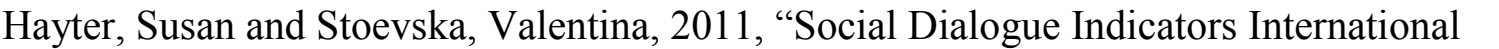

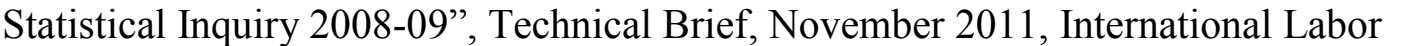

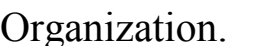

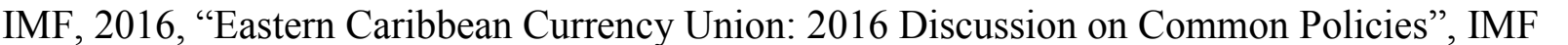

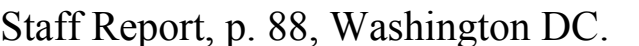

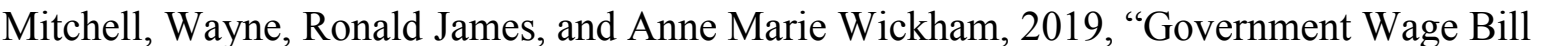

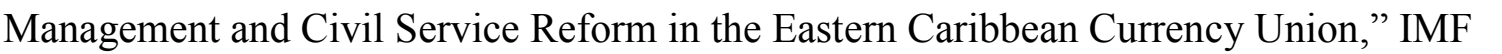

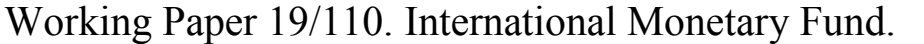

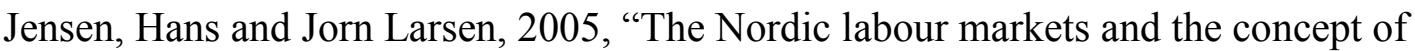

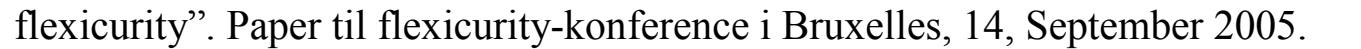

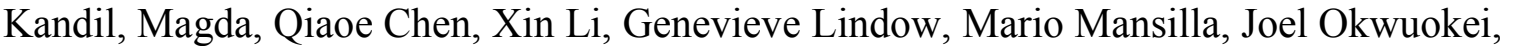

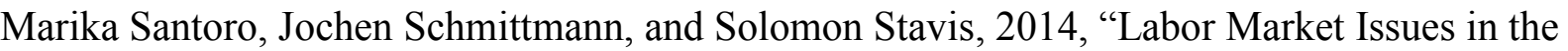

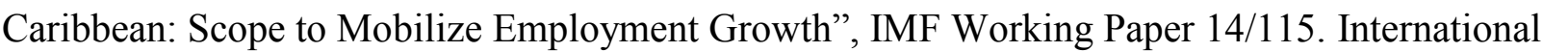

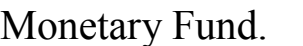

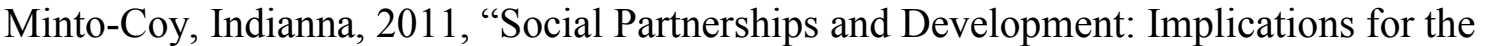

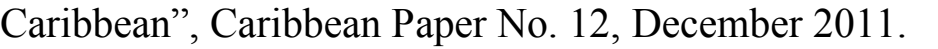

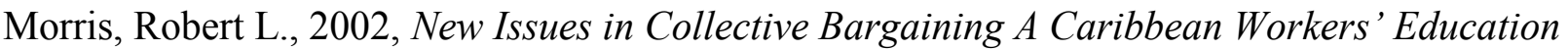

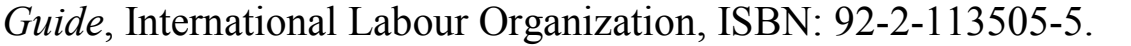




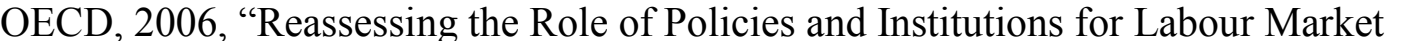

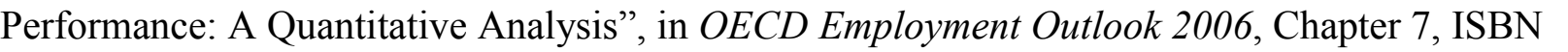

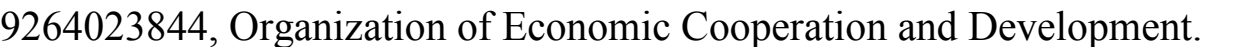

Orlandi, Fabrice, 2012, “

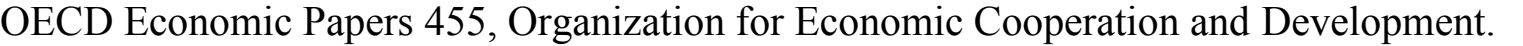

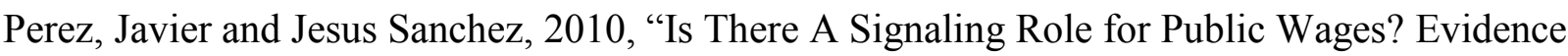

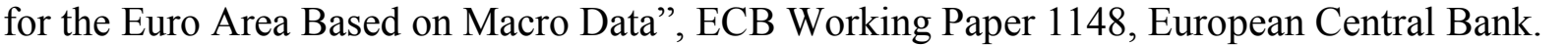

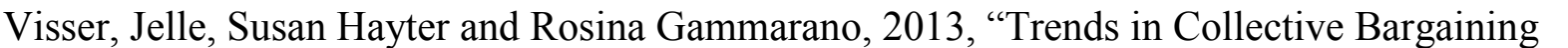

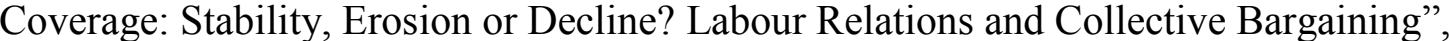

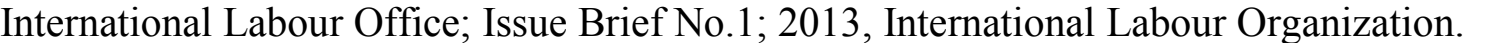

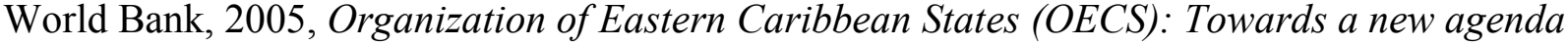
for growth

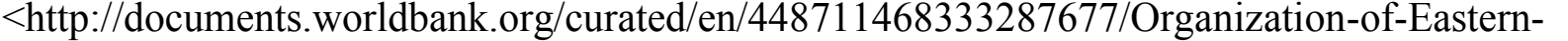

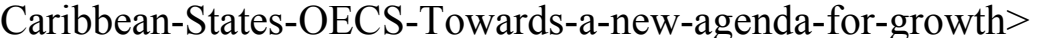

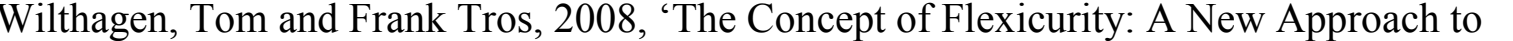

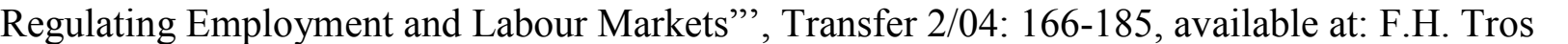

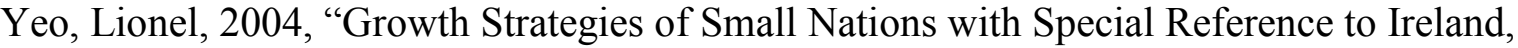

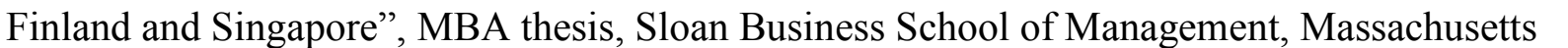

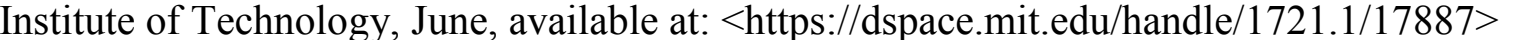


Annex 1

Recommended Reforms to Labor Market Arrangements

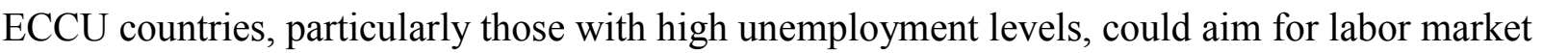

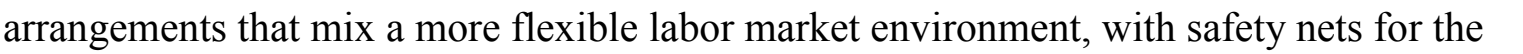

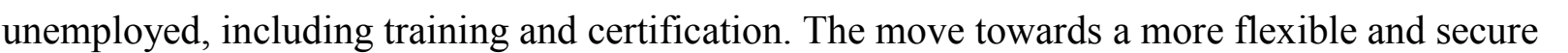
प

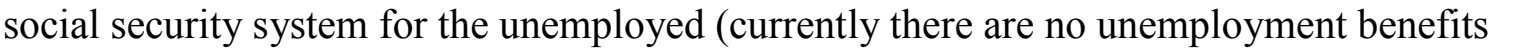

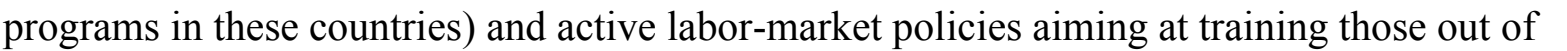

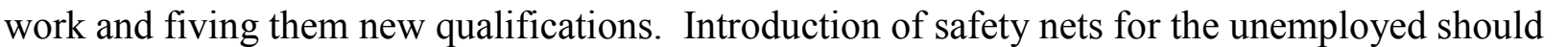

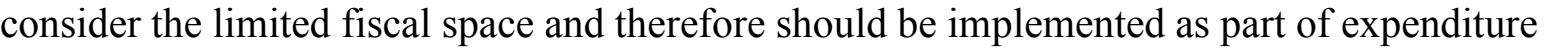

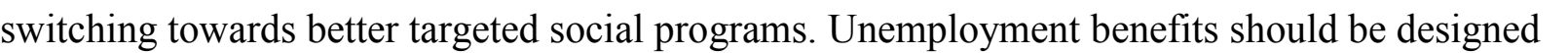
Wstrike a balance between providing support and encouraging labor participation. Barbados’

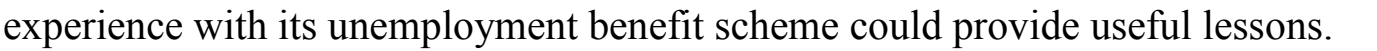
$\square$

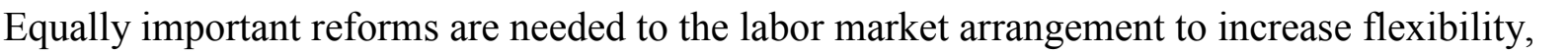

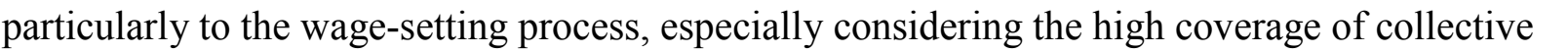

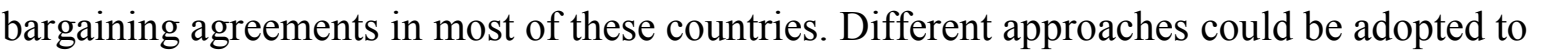

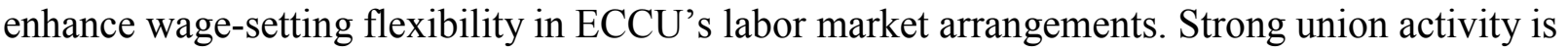

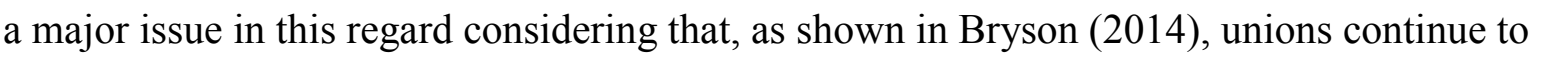

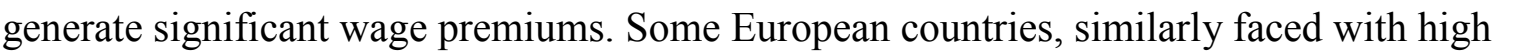

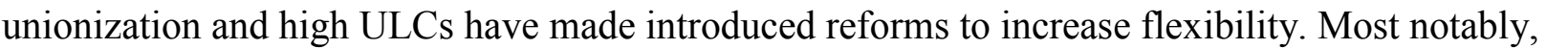

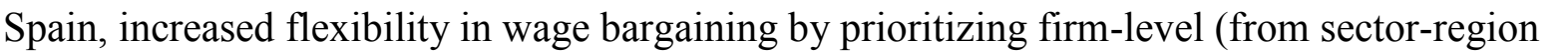

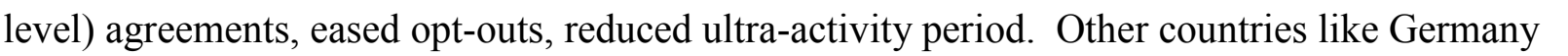
ए ए। ए एव $\square$

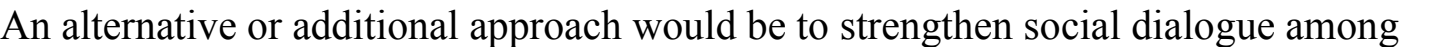

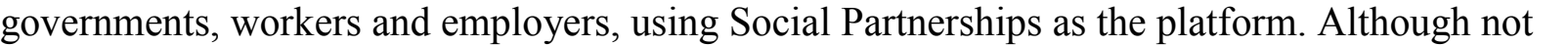

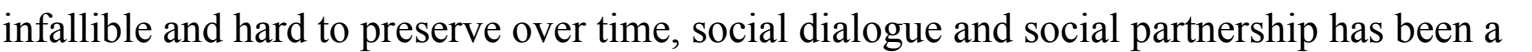

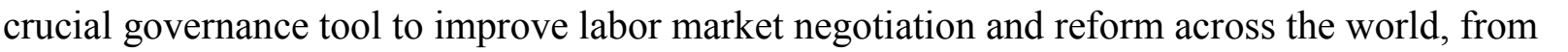
ए ए

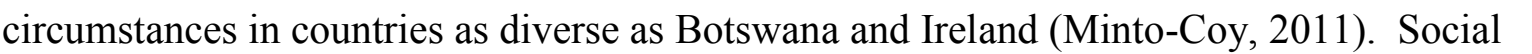

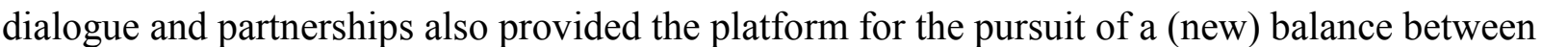

'flexibility' and 'security' [which] is especially manifest within the European [Union] 


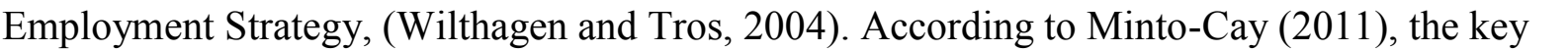

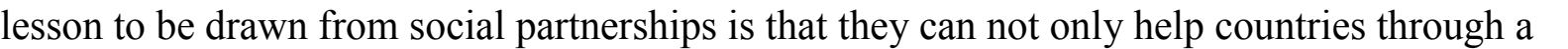

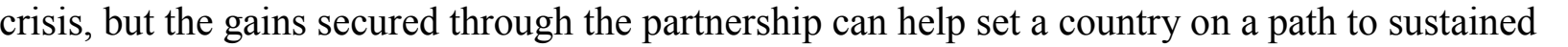

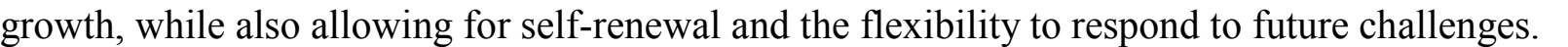
$\square$

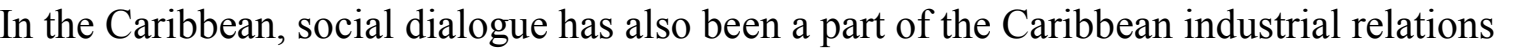

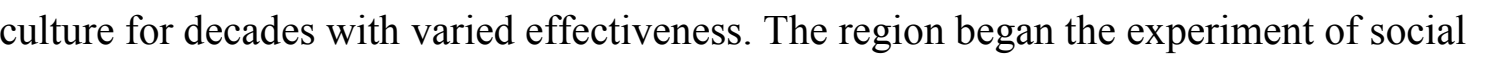

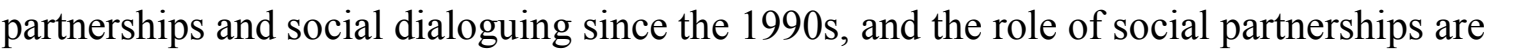

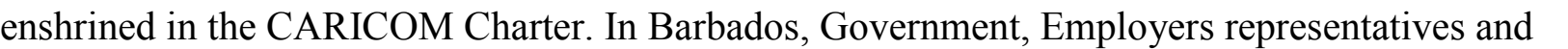

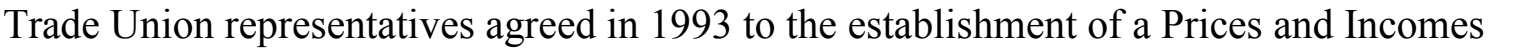

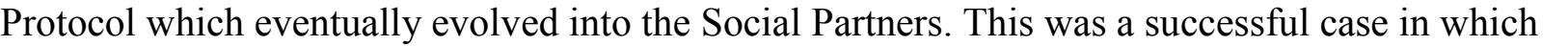

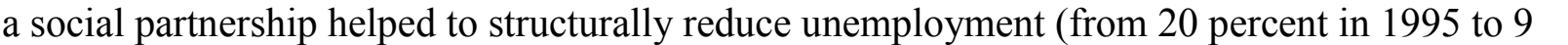

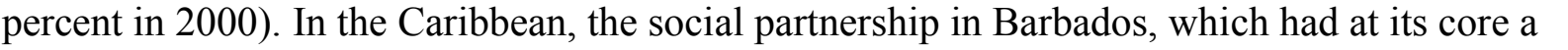

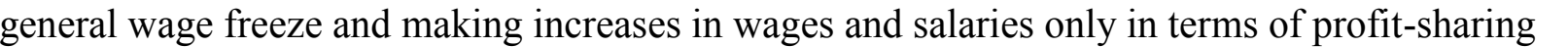

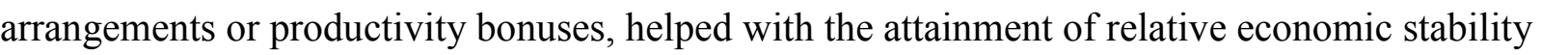

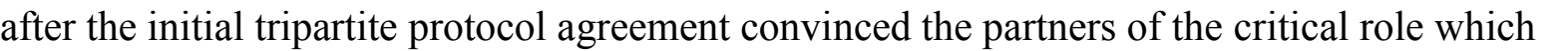

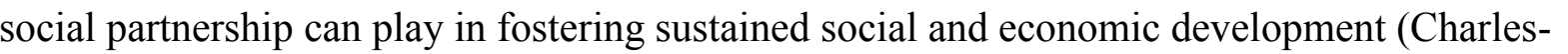

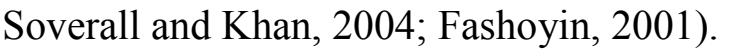

$\square$

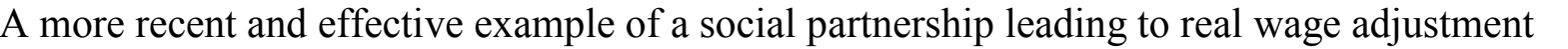

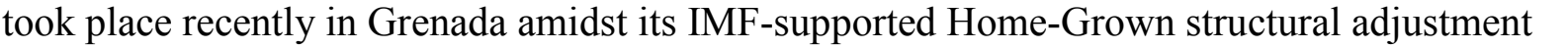

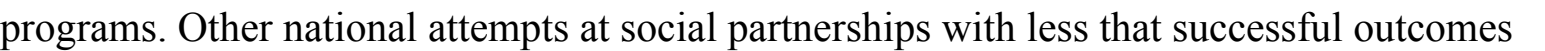

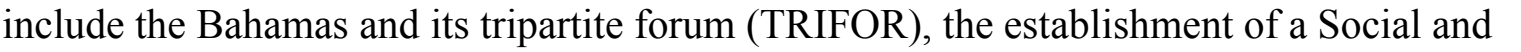

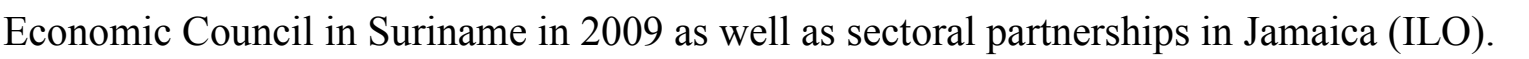
$\square$

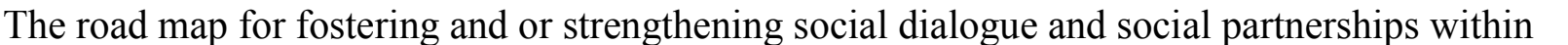

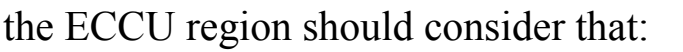

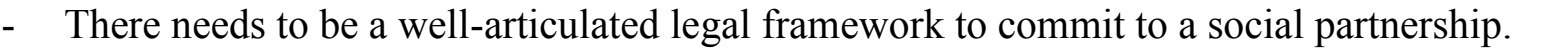

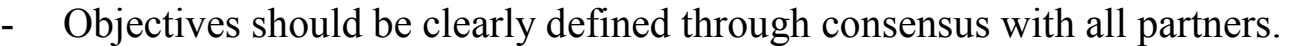

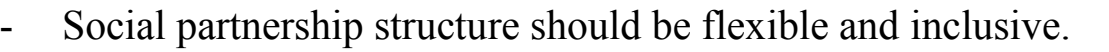

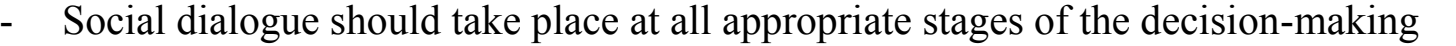
$\square\|11\| \|$

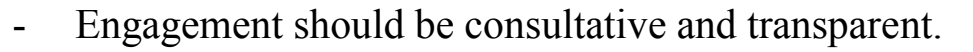

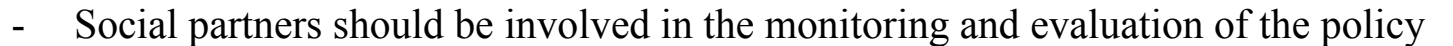
एणाएवा 